PRELIMINARY INTERPRETIVE REPORT 2013-5

\title{
PETROLOGY AND RESERVOIR POTENTIAL OF TERTIARY AND MESOZOIC SANDSTONES, COOK INLET, ALASKA: A PRELIMINARY ANALYSIS OF OUTCROP SAMPLES COLLECTED DURING 2007-2010 FIELD SEASONS
}

by

Kenneth P. Helmold, David L. LePain, Michael D. Wilson, and C. Shaun Peterson

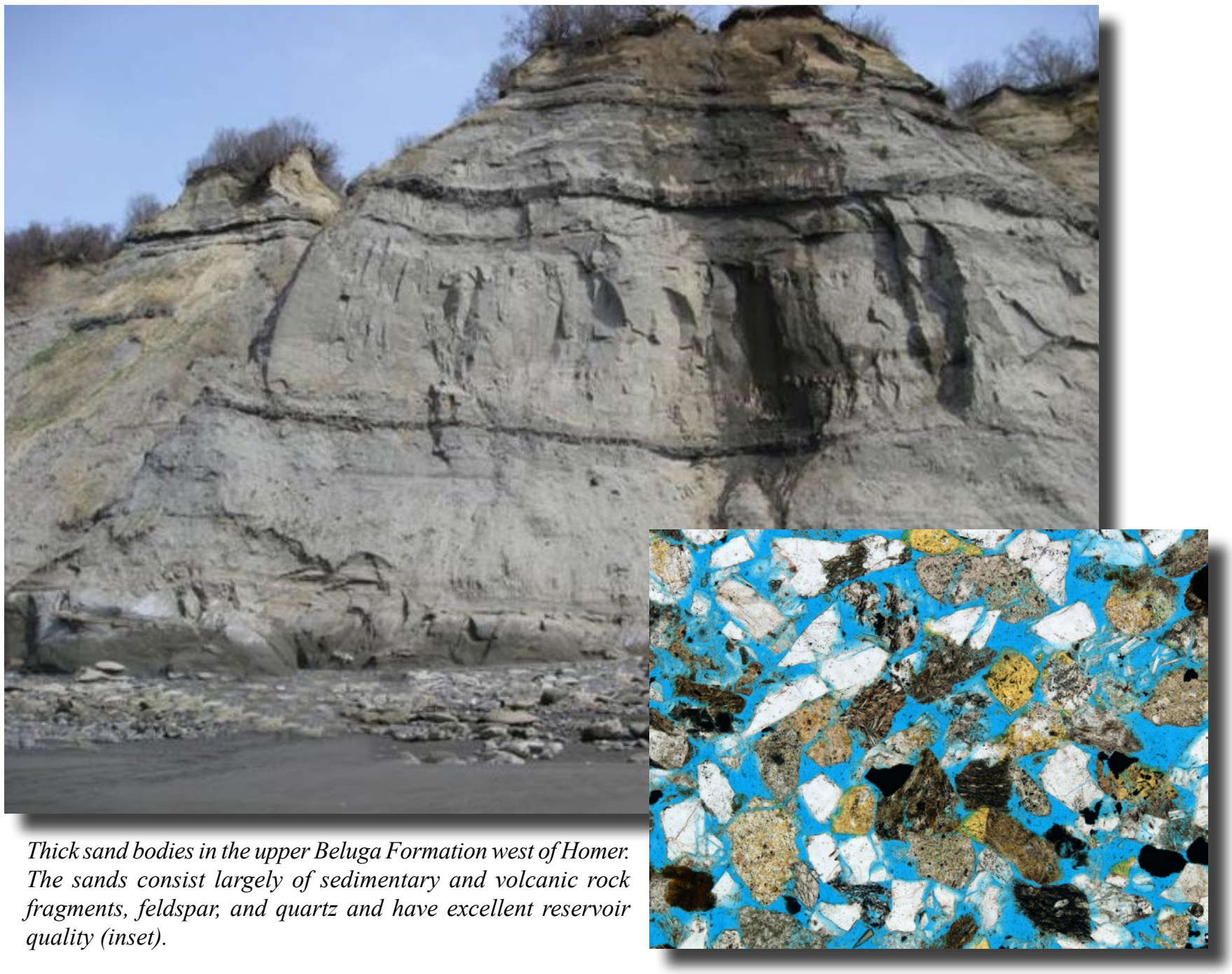

April 2013

Released by

STATE OF ALASKA

DEPARTMENT OF NATURAL RESOURCES

Division of Geological \& Geophysical Surveys

3354 College Rd.. Fairbanks, Alaska 99709-3707 



\section{CONTENTS}

Introduction. 1

Data sets. 1

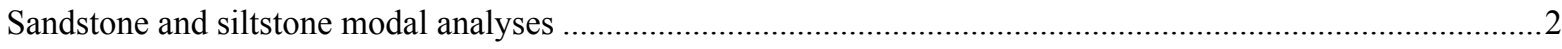

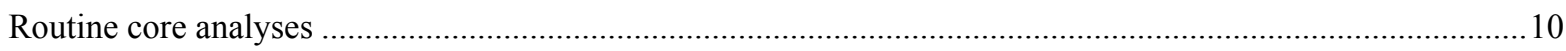

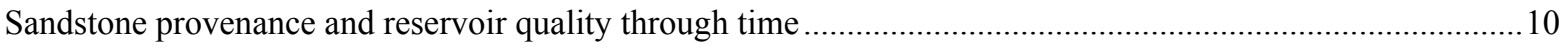

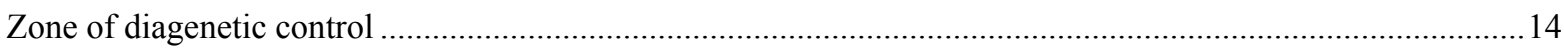

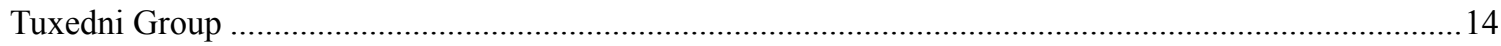

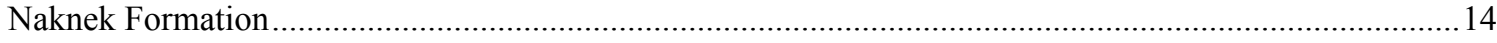

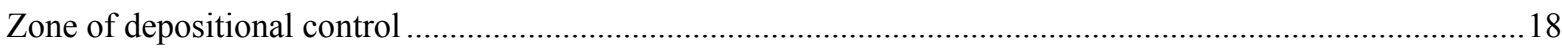

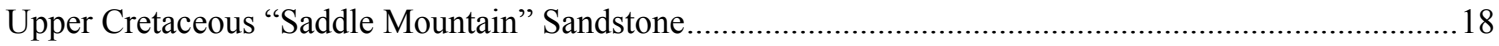

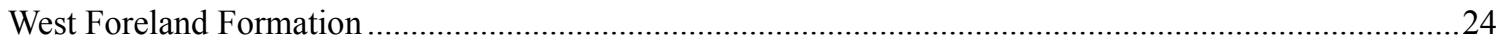

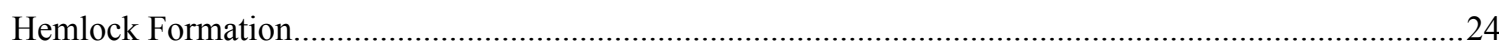

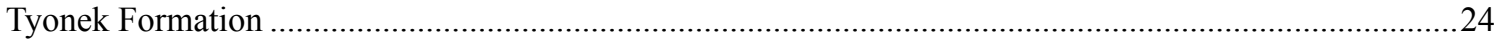

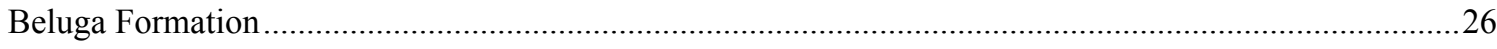

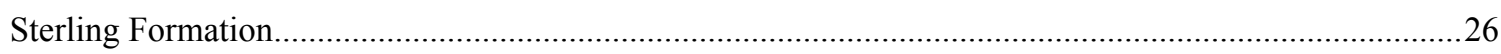

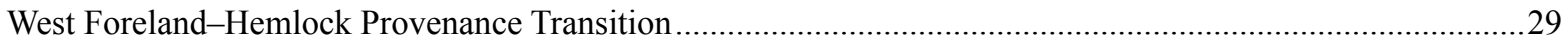

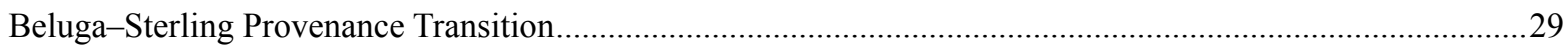

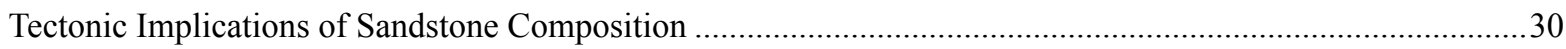

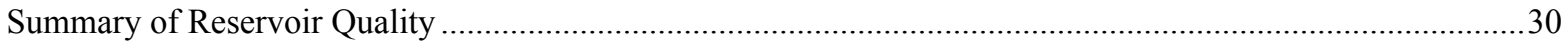

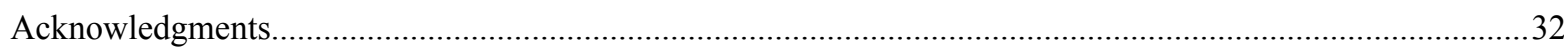

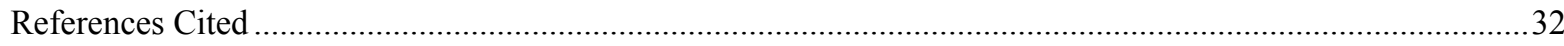

\section{TABLES}

Table 1. provided in .pir2013-00X-sample-location-details.csv

2-6. provided in pir2013-00X-raw-and-summary-data.xlsx

7. Classification of Grain and Intergranular Parameters .10

\section{FIGURES}

Figure 1. Stratigraphic column for Tertiary and Mesozoic sections of Cook Inlet basin showing the zones

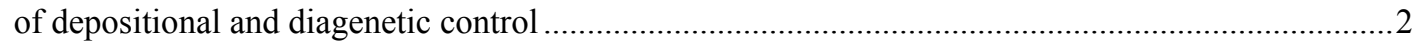

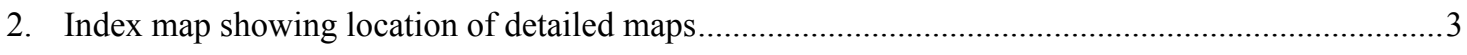

3. Map showing distribution of Tertiary samples in Homer area......................................................4

4. Map showing distribution of Tertiary samples at Clam Gulch .............................................5

5. Map showing distribution of Tertiary samples in Beluga-Tyonek area .........................................6

6. Map showing distribution of Tertiary samples in the Straight Creek-Capps Glacier area .................7

7. Map showing distribution of Mesozoic samples in Tuxedni Bay-Chisik Island area ......................8

8. Map showing distribution of Mesozoic samples on Iniskin Peninsula............................................ 
9. Photographs illustrating the various techniques used for sampling unconsolidated sediments.

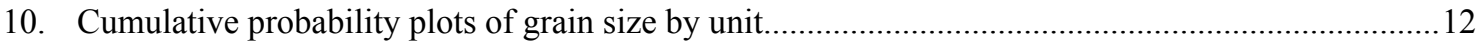

11. Ternary diagrams showing composition of Tertiary and Mesozoic sandstones...............................13

12. Ternary diagrams suggesting the West Foreland-Hemlock provenance transition ..........................14

13. Diagrams documenting the Beluga-Sterling provenance transition........................................15

14. Ternary diagrams showing representative detrital modes of selected suites of Mesozoic and

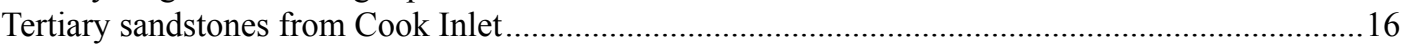

15. Porosity-permeability cross plot showing reservoir quality of Tertiary and Mesozoic sandstones

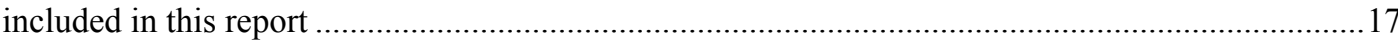

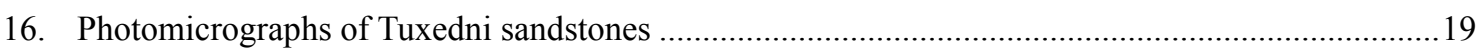

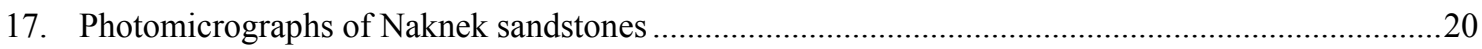

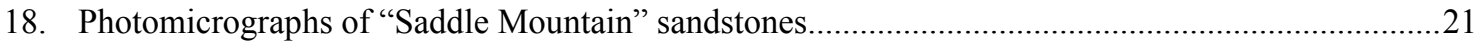

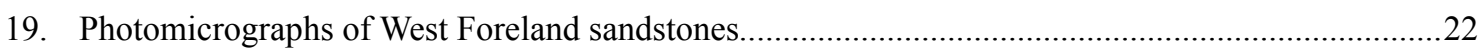

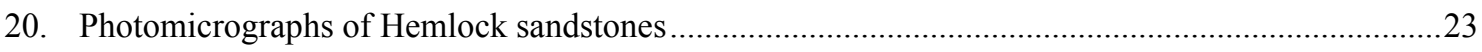

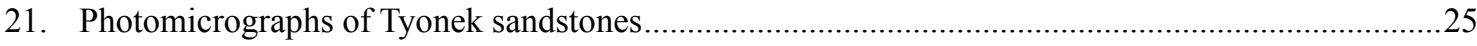

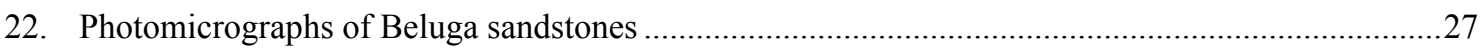

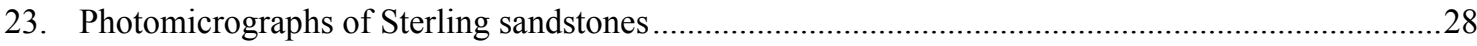




\title{
PETROLOGY AND RESERVOIR POTENTIAL OF TERTIARY AND MESOZOIC SANDSTONES, COOK INLET, ALASKA: A PRELIMINARY ANALYSIS OF OUTCROP SAMPLES COLLECTED DURING 2007-2010 FIELD SEASONS
}

\author{
by \\ Kenneth P. Helmold ${ }^{1}$, David L. LePain ${ }^{2}$, Michael D. Wilson ${ }^{3}$, and C. Shaun Peterson ${ }^{1}$
}

\section{INTRODUCTION}

The State of Alaska Division of Geological \& Geophysical Surveys (DGGS) and Division of Oil \& Gas (DOG) are currently engaged in a multi-year study of the hydrocarbon potential of the Tertiary and Mesozoic strata in Cook Inlet basin (fig. 1). The study was initiated in 2006 and is currently ongoing with more than 60 outcrop sections measured from both the east and west sides of the basin (fig. 2). The initial work focused on Tertiary sections on the Kenai Peninsula from Homer (fig. 3) northward to Clam Gulch (fig. 4). Subsequent Tertiary sections were measured on the west side of Cook Inlet from Lewis River (fig. 5) westward to Straight Creek (fig. 6). Sections of Mesozoic strata were measured in lower Cook Inlet along the shores of Tuxedni Bay (fig. 7) and the Iniskin Peninsula (fig. 8). Samples keyed to these measured sections have been collected for petrography, routine core analysis (porosity and permeability), palynology, $\mathrm{U}-\mathrm{Pb}$ and ${ }^{40} \mathrm{Ar}-{ }^{39} \mathrm{Ar}$ age dating, chemostratigraphy, mercury injection capillary pressure (MICP), and detrital apatite and zircon analyses. This report presents only the petrographic and routine core-analysis data, and provides preliminary interpretations of them. It should be considered a progress report, as additional samples from the 2011-2013 field seasons are currently being analyzed (Helmold, 2013; Herriott and others, 2013) and additional fieldwork is planned for the summer of 2013. This report will be updated and amended as additional data become available.

\section{DATA SETS}

Two hundred-seventeen (217) modal analyses and 188 routine core analyses were performed on Tertiary and Mesozoic siltstones and sandstones collected during the 2007-2010 field seasons, from six geographic areas in upper and lower Cook Inlet (figs. 2-8). Initial formation assignment for each sample was based on previously published maps and ongoing DGGS/DOG fieldwork in the area. In some cases assignments were modified after the modal data were analyzed to ensure petrographically similar samples were included in the same unit. In a few cases, there is still some disagreement among workers as to the actual formation calls. In this report, when in doubt, emphasis is given to the petrographic character of the rocks.

This data is provided to users as an online digital data download. The digital data can be downloaded from http://www.dggs.alaska.gov/pubs/id/25035. The download file contains:

A CSV file with sample location details, map and sample reference numbers, geographic location, latitude, longitude, and formation assignment.

An XLSX workbook providing raw and summary data. The spreadsheet is organized into the following tabbed worksheets:

Table 2. Raw petrographic data in original format provided by Michael D. Wilson.

Table 3. Raw petrographic data converted to format of Decker-Helmold.

Table 4. Summary of petrographic data.

Table 5. Grain size data in $\varphi$ (phi) units.

Table $6 . \quad$ Routine core analysis conducted by Weatherford Labs, Inc.

\footnotetext{
${ }^{1}$ Alaska Division of Oil \& Gas, 550 W. $7^{\text {th }}$ Avenue, Anchorage, Alaska 99501; ken.helmold@alaska.gov

${ }^{2}$ Alaska Division of Geological \& Geophysical Surveys, 3354 College Road, Fairbanks, Alaska 99709-3707

${ }^{3}$ Wilson \& Associates, 12255 W. $17^{\text {th }}$ Avenue, Lakewood, Colorado 80215
} 


\section{SANDSTONE AND SILTSTONE MODAL ANALYSES}

The modal analyses were conducted by Michael D. Wilson, a geological consultant in Lakewood, CO. He counted a minimum of 300 grains via the traditional point-counting method (Decker and Helmold, 1985) to determine the composition of the framework (detrital grains) and intergranular components (matrix, cement, porosity). A second count of 200 grains (including matrix) was conducted for grain size. The modal analyses are presented in two formats: (1) Wilson, and (2) Decker-Helmold. The original raw (non-interpreted) data provided by Wilson are presented in table 2 . These data are converted into a hierarchical format originally devised by Decker (1985) and are presented in table 3. The Decker-Helmold-formatted table also displays standard petrologic parameters

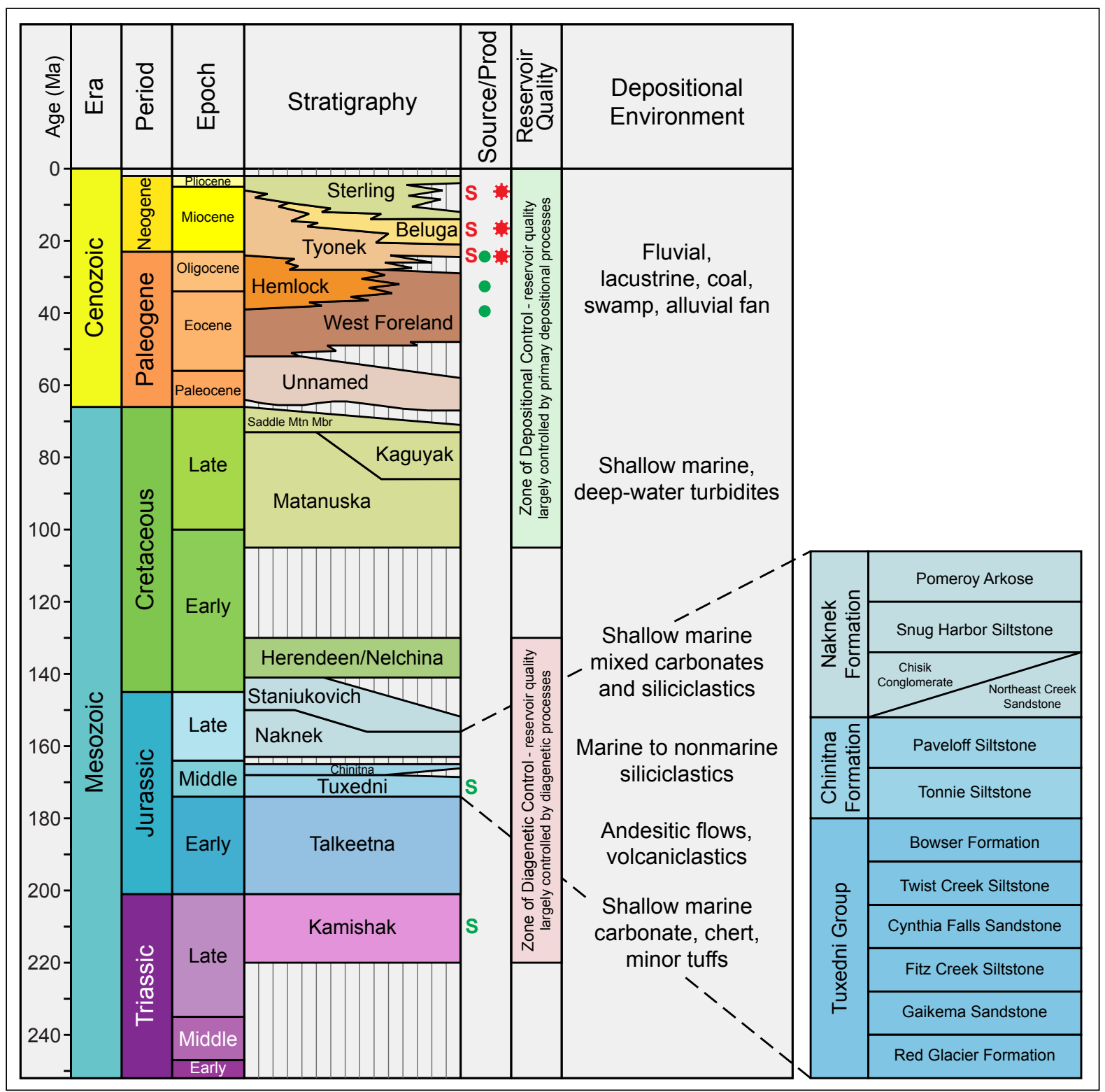

Figure 1. Stratigraphic column for Tertiary and Mesozoic sections of Cook Inlet basin showing the zone of depositional control with generally good reservoir quality and zone of diagenetic control with poor reservoir quality. $S=$ oil-prone marine source rock; $S=$ gas-prone nonmarine source rock including lignitic coal and carbonaceous mudstone; = =il reservoir; * =gas reservoir. Redrawn from Curry and others (1990) and Swenson (2003) with additional information from Little and Naeser (1989), Plafker and others (1989), and Nokleberg and others (1994). Stratigraphic variations and lateral inter-tonguing are depicting basin-margin to basin-center relationships. 


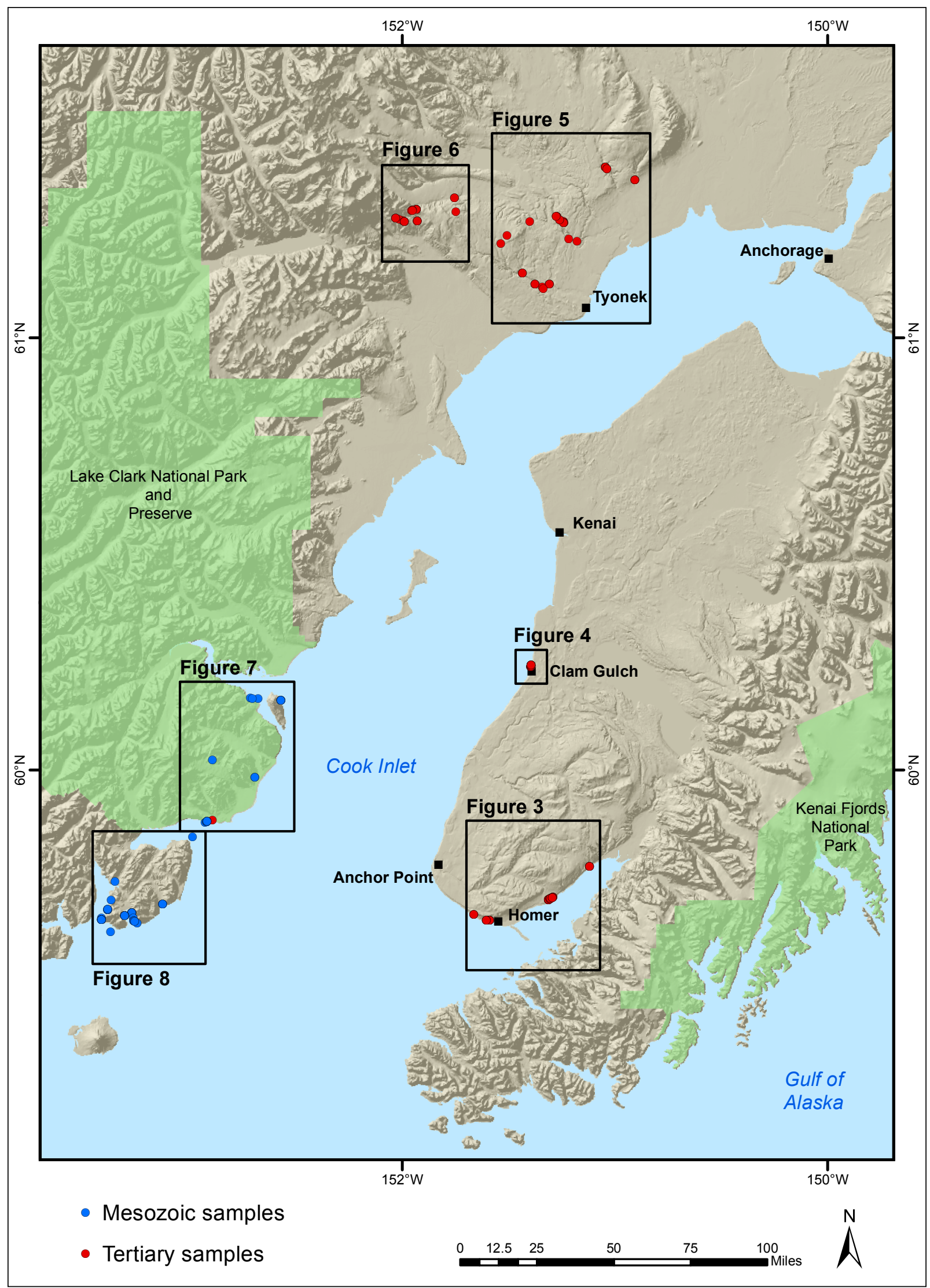

Figure 2. Index map showing location of detailed maps. 


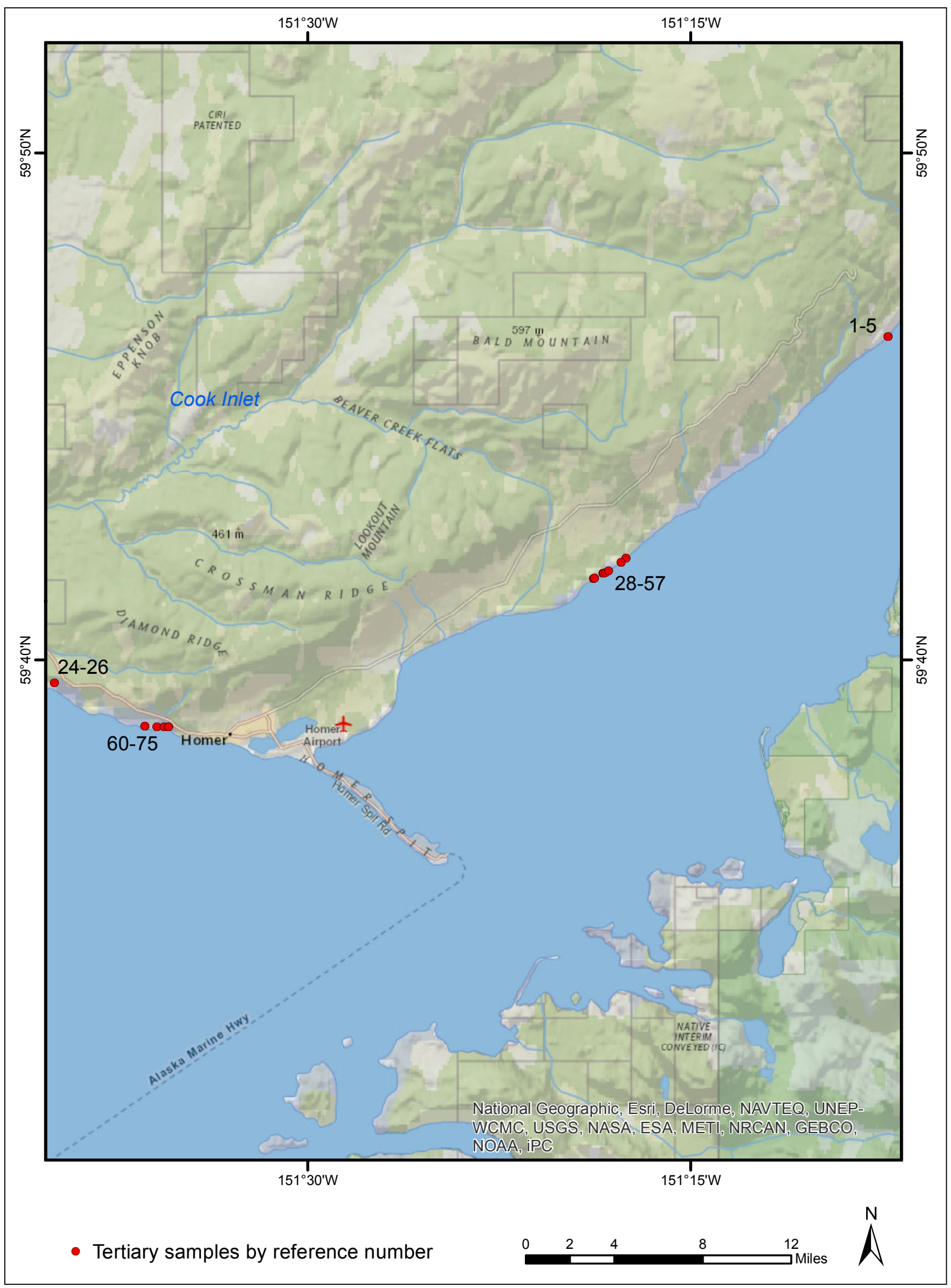

Figure 3. Map showing distribution of Tertiary samples in Homer area. Reference numbers refer to samples listed in table 1. 
and ternary ratios to facilitate interpretation of the data. This allows individuals to use the data in its original or its modified format. A summary of the Decker-Helmold-formatted data, in which individual counts are grouped into meaningful categories, is provided in table 4 . The grain-size data, measured in $\varphi$ (phi) units, are shown in table 5 . The data are sorted in order of increasing grain size to facilitate calculation of cumulative percentages for display in grain-size plots (fig. 10).

The point-count data are displayed graphically on several ternary plots (fig. 11) and the parameters used in the plots are summarized in table 7. Interpretations of tectonic setting based on detrital modes are facilitated by QtFL and QpLvmLsm diagrams on which the provenance fields of Dickinson (1985) are superimposed (fig. 14). It is important to recognize that while our data were collected using the traditional point-counting method (Decker and Helmold, 1985), the data on which Dickinson constructed his provenance fields were collected using the Gazzi-Dickinson point-counting method (Gazzi, 1966; Dickinson, 1970; Ingersoll and others, 1984). Our data were converted to an

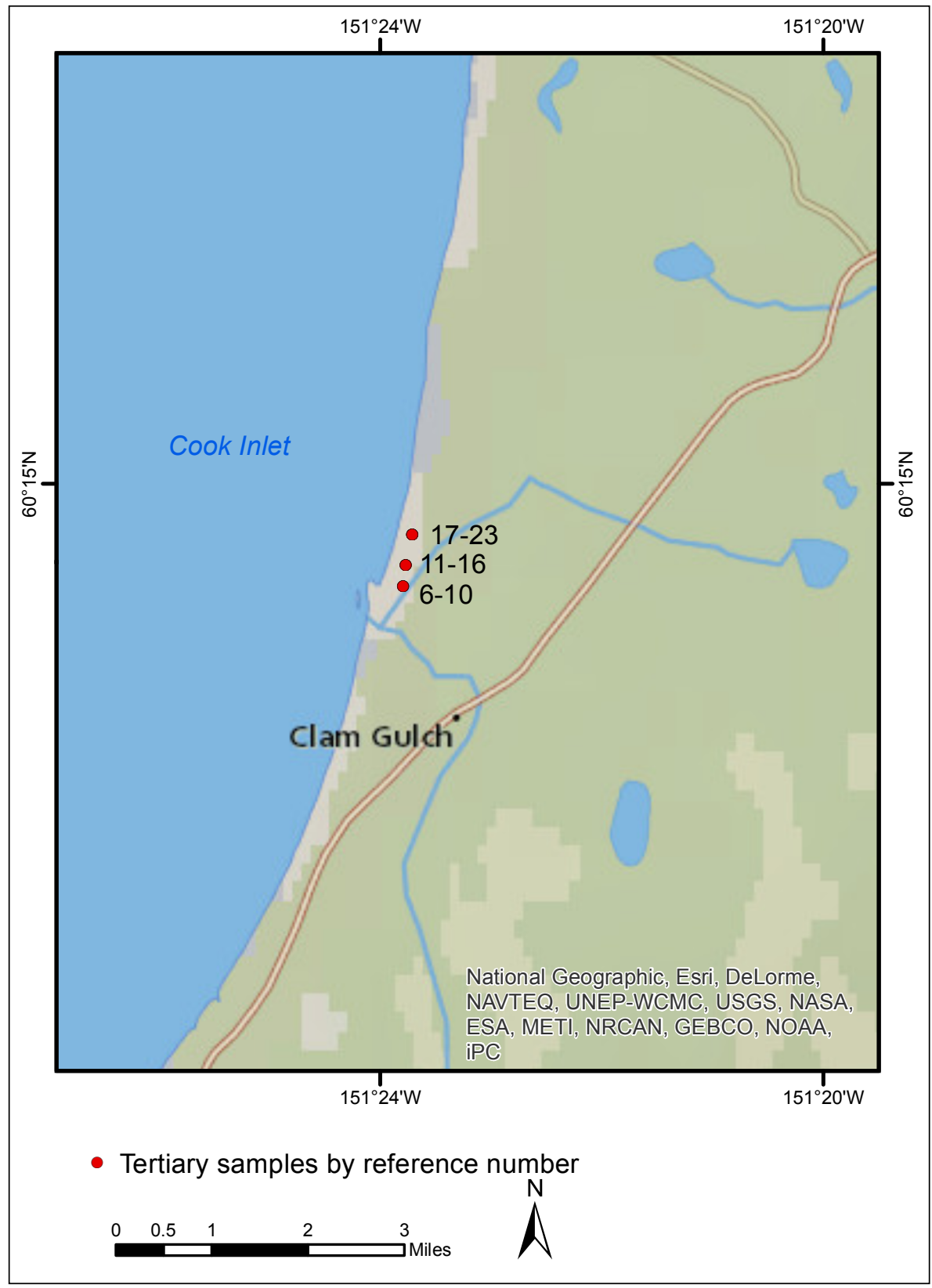

Figure 4. Map showing distribution of Tertiary samples at Clam Gulch. Reference numbers refer to samples listed in table 1. 


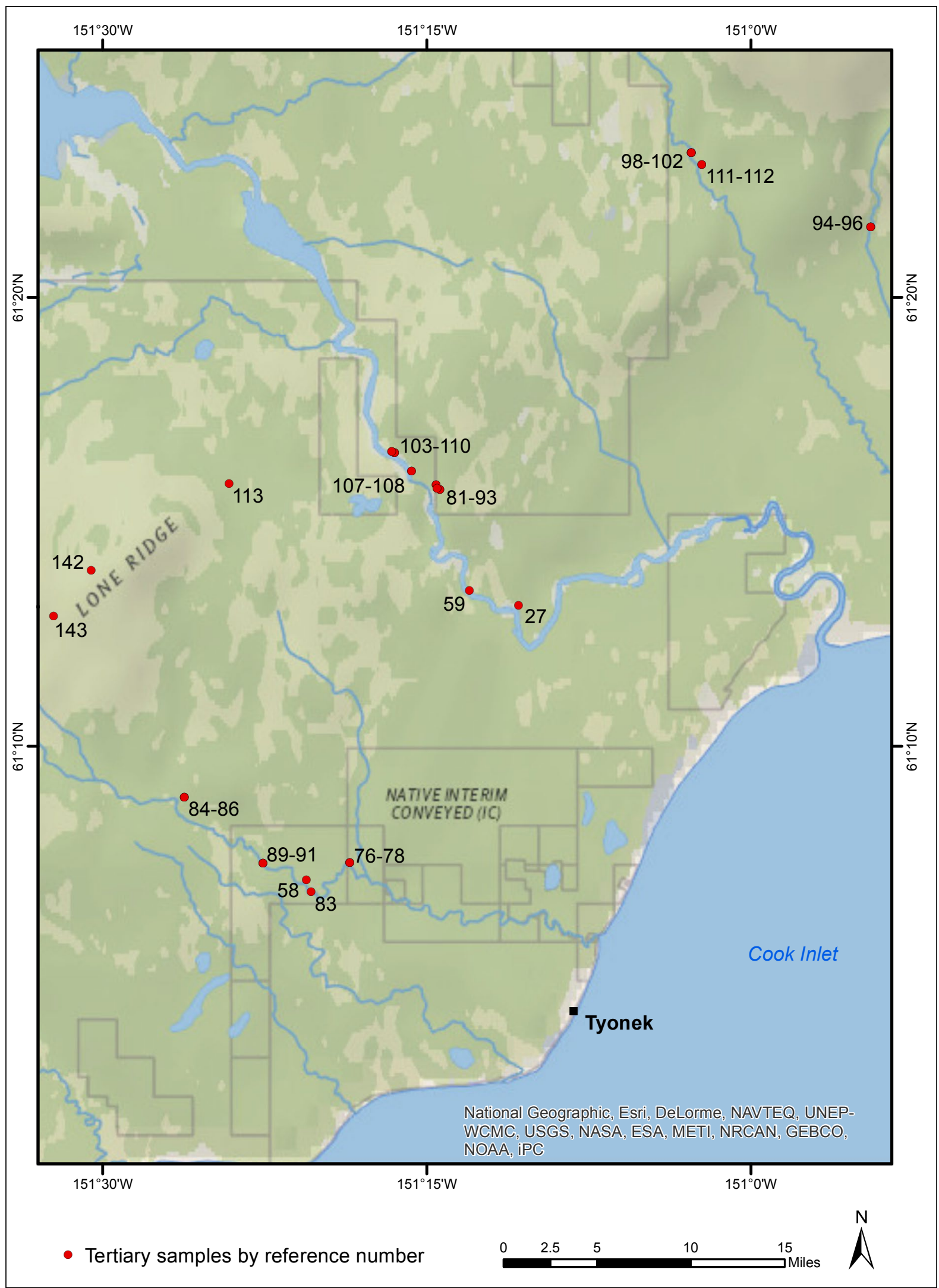

Figure 5. Map showing distribution of Tertiary samples in Beluga-Tyonek area. Reference numbers refer to samples listed in table 1. 


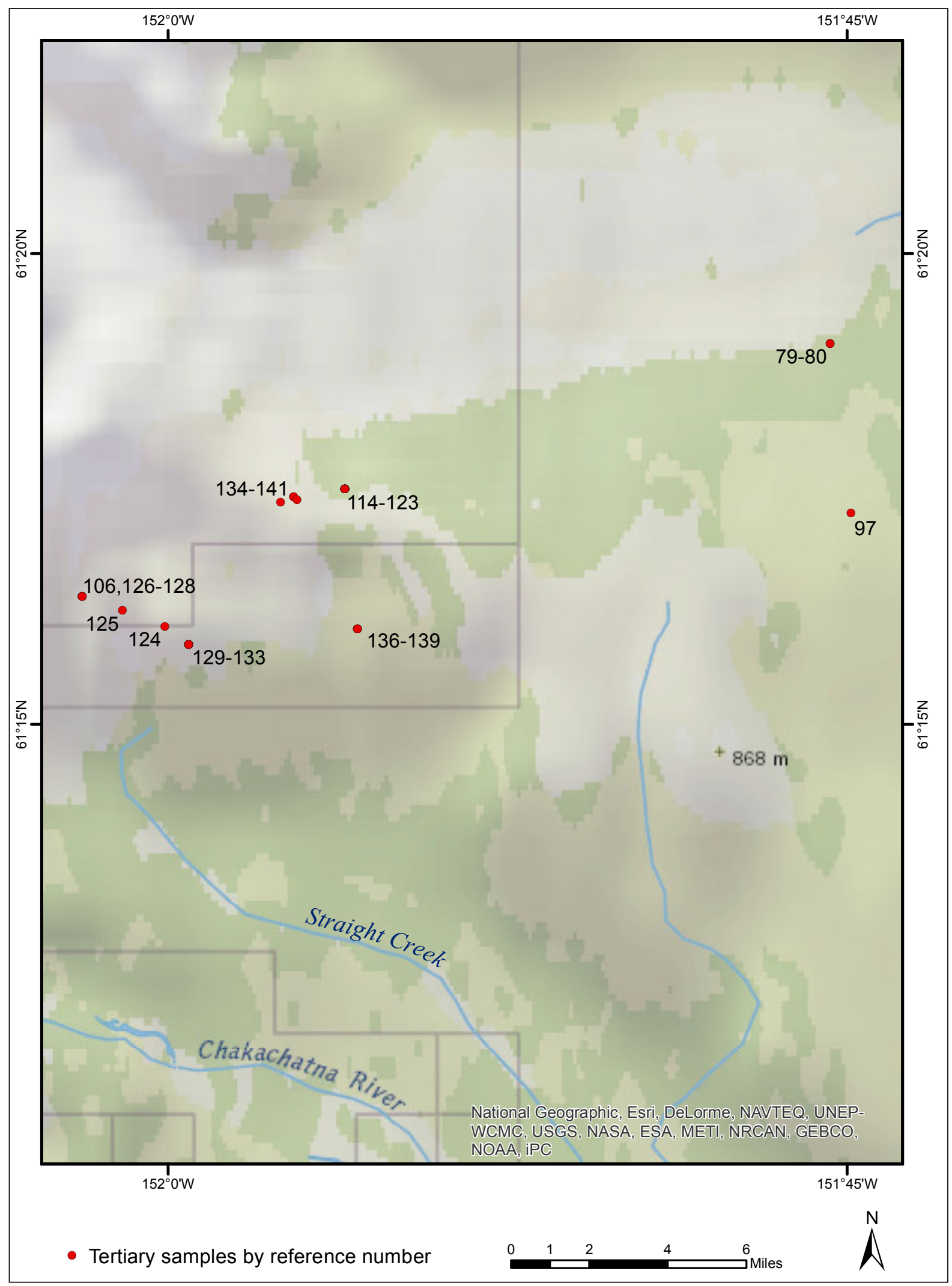

Figure 6. Map showing distribution of Tertiary samples in the Straight Creek-Capps Glacier area. Reference numbers refer to samples listed in table 1. 


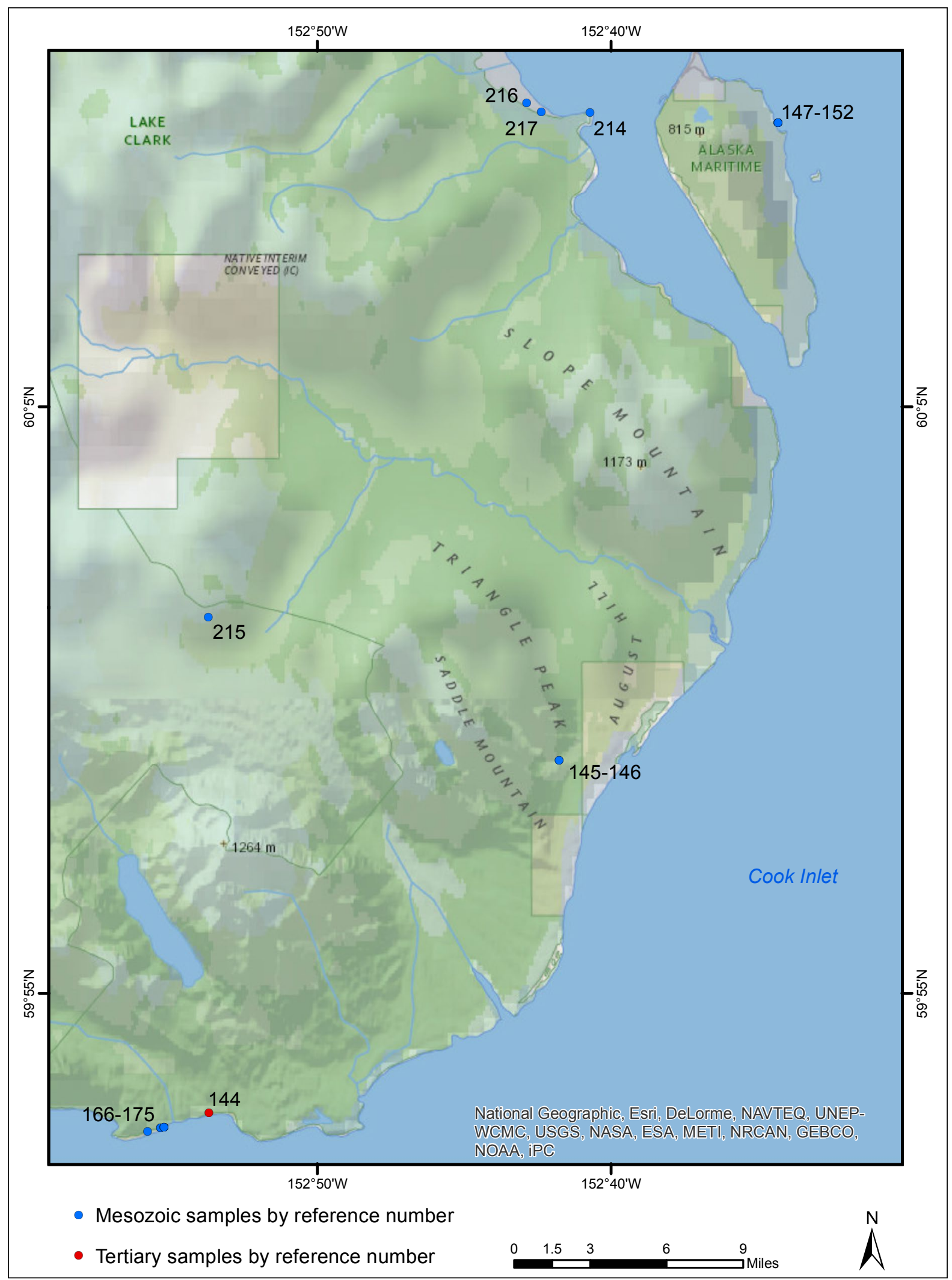

Figure 7. Map showing distribution of Tertiary and Mesozoic samples in Tuxedni Bay-Chisik Island area. Reference numbers refer to samples listed in table 1. 


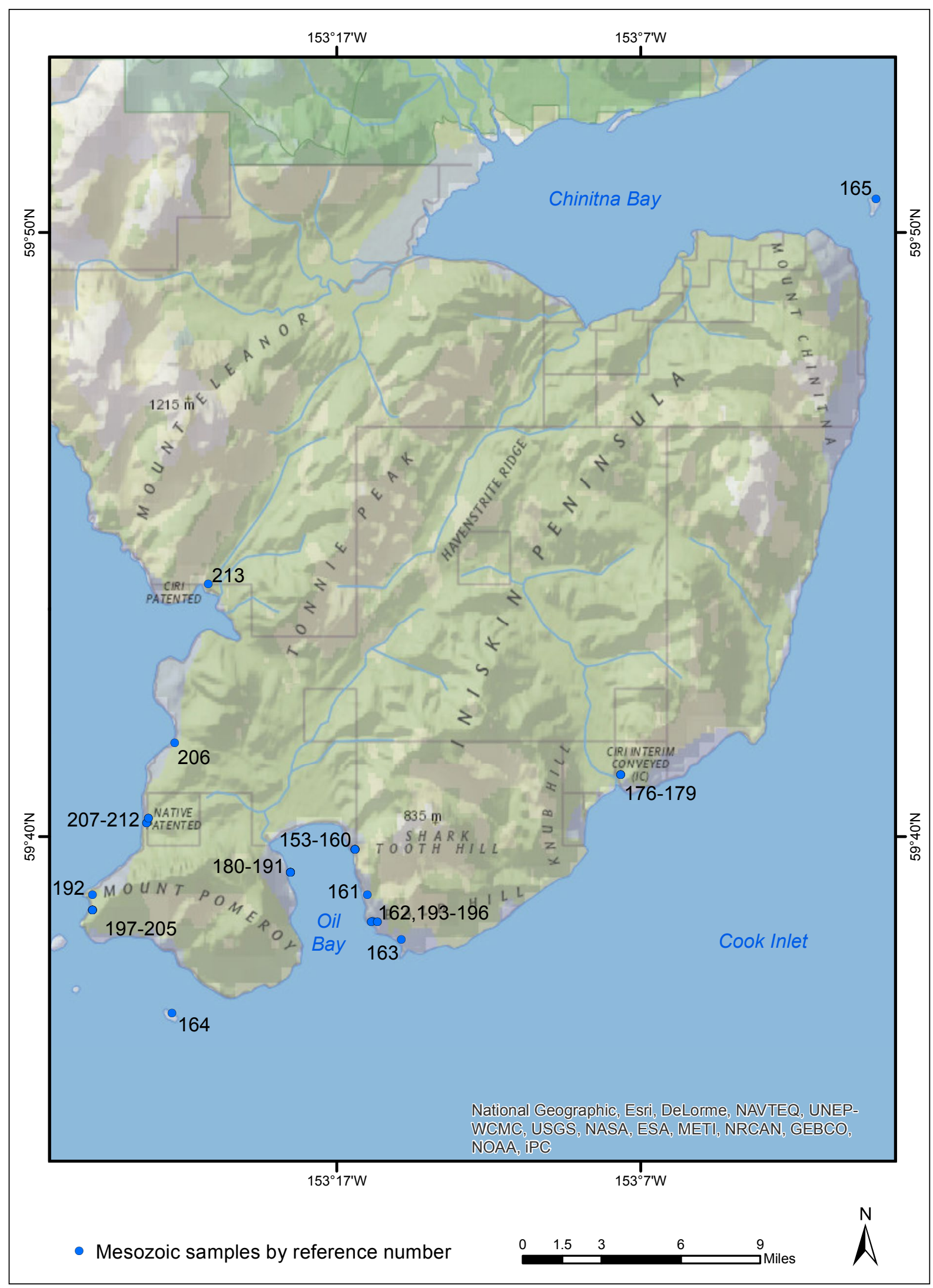

Figure 8. Map showing distribution of Mesozoic samples on Iniskin Peninsula. Reference numbers refer to samples listed in table 1. 
Table 7. Classification of Grain and Intergranular Parameters
A. Quartzose grains
$\mathrm{Qm}=$ Monocrystalline quartz
$\mathrm{Qp}=$ Polycrystalline quartz (including chert)
$\mathrm{Qt}=$ Total quartzose grains $(\mathrm{Qm}+\mathrm{Qp})$
B. Feldspar grains
$\mathrm{P}=$ Plagioclase
$\mathrm{K}=$ Potassium feldspar
$\mathrm{F}=$ Total feldspar grains $(\mathrm{P}+\mathrm{K})$
C. Lithic grains

$\mathrm{Ls}=$ Sedimentary rock fragments (including chert)
$\mathrm{Lv}=$ Volcanic rock fragments
$\mathrm{Lm}=$ Metamorphic rock fragments
$\mathrm{Lp}=$ Plutonic rock fragments
$\mathrm{Lsm}=$ Sedimentary and metasedimentary rock fragments
$\mathrm{Lvm}=$ Volcanic and metavolcanic rock fragments
$\mathrm{L}=$ Lithic grains (Ls excluding chert $+\mathrm{Lv}+\mathrm{Lm}+\mathrm{Lp})$
$\mathrm{Lt}=$ Total lithic grains $(\mathrm{L}+\mathrm{Qp})$
D. Intergranular components
$\begin{array}{lll}\Phi & =\text { Total porosity } \\ \mathrm{C} & = & \text { Total cement } \\ \mathrm{M} & = & \text { Matrix }+ \text { clay laminae/burrows }\end{array}$

equivalent Gazzi-Dickinson format by making geologically reasonable assumptions concerning the composition of the plutonic rock fragments (PRFs) using the procedure of Wilson (2002). Based on petrographic examination of the plutonic rock fragments, felsic $P R F s$ were assigned the composition $\mathrm{Q}_{40} \mathrm{P}_{30} \mathrm{~K}_{30} \mathrm{~A}_{0}$, where $\mathrm{Q}=$ quartz, $\mathrm{P}=$ plagioclase, $\mathrm{K}=\mathrm{K}$-feldspar, and $\mathrm{A}=$ amphibole. Similarly, intermediate $\mathrm{PRFs}$ were assigned the composition $\mathrm{Q}_{10} \mathrm{P}_{60} \mathrm{~K}_{10} \mathrm{~A}_{20}$ and mafic PRFs the composition $\mathrm{Q}_{0} \mathrm{P}_{70} \mathrm{~K}_{0} \mathrm{~A}_{30}$. These reformatted data are used to produce figure 14 .

\section{ROUTINE CORE ANALYSES}

The routine core analyses (including several duplicate samples) were performed by Weatherford Labs, Inc. in their Anchorage, Alaska, and Casper, Wyoming, facilities (table 6). Many of the outcrops sampled have not been deeply buried and hence are relatively unlithified. This is of critical importance to routine core analyses because loosely consolidated and disrupted samples can yield anomalous data, particularly for permeabilities. Several techniques were tested to produce good quality, undisrupted samples, including portable electric drills, conduit pipes, small juice cans, and electrical boxes (fig. 9A). All of these failed for various reasons. After much experimentation a procedure was developed to acquire usable samples that could be plugged for analysis. This entailed excavating large "bread-loaf" sized samples (figs.9B, C) that were immediately wrapped in several layers of plastic wrap (fig. 9D) and secured in canvas bags with duct tape (fig. 9E). These samples were later placed in plastic bags and covered with a thin coating of epoxy resin prior to shipping (fig. 9F). The analysis of thin sections from these friable samples shows most of them are intact, with only minor disruption to the rock fabric visible in some samples.

\section{SANDSTONE PROVENANCE AND RESERVOIR QUALITY THROUGH TIME}

Sandstones of Cook Inlet basin can be divided into two informal groups based on reservoir quality (fig. 1). Sandstones of Middle Jurassic to Early Cretaceous age comprise the 'zone of diagenetic control', where reservoir quality is largely a function of the compaction and cementation history of the rocks. These sandstones generally have a labile mineralogy, are relatively old, and have been buried to substantial depths, resulting in considerable modifications to depositional texture and mineralogy. Sandstones of Late Cretaceous to Pliocene age comprise 

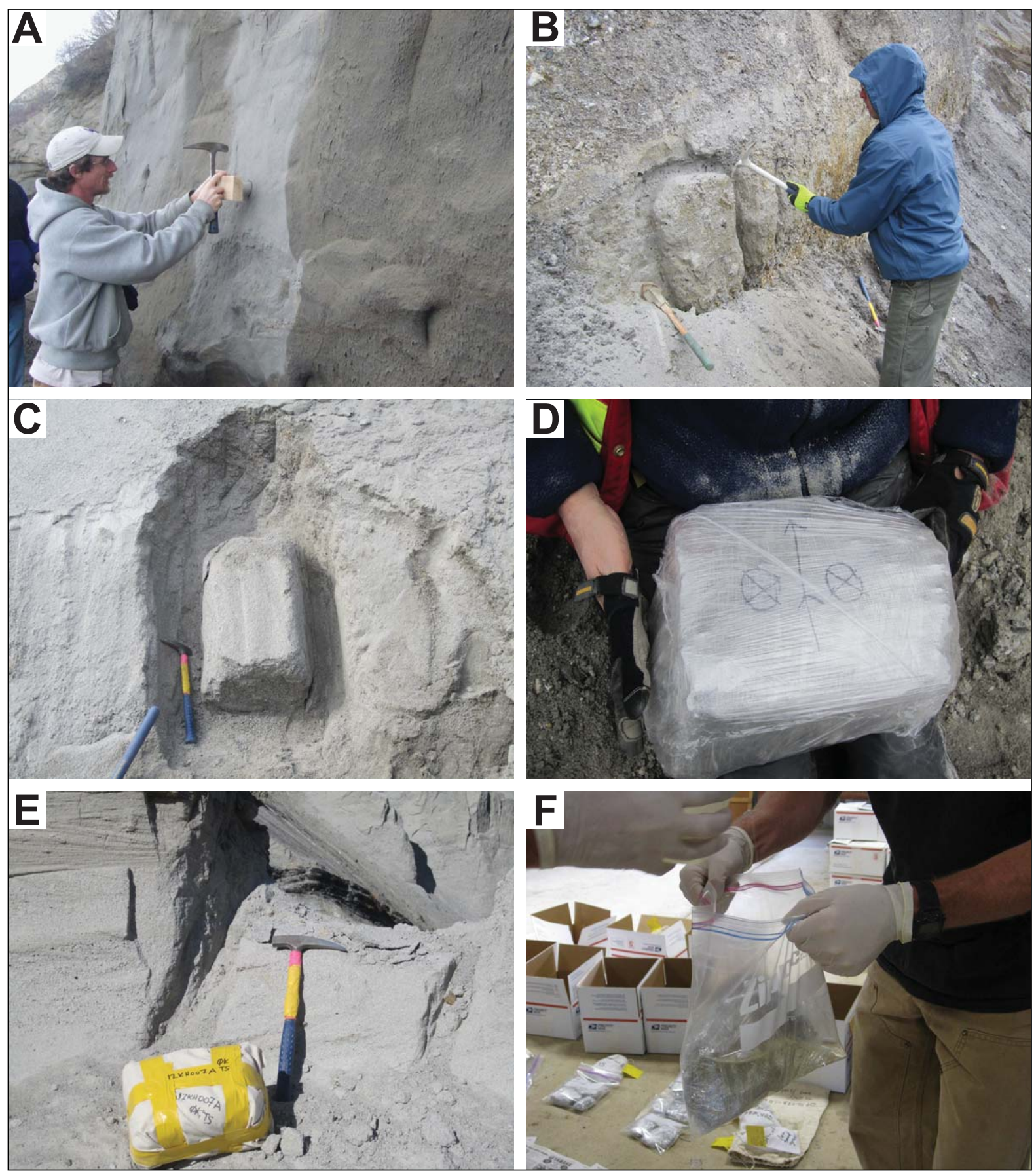

Figure 9. Photographs illustrating the various techniques used for sampling unconsolidated sediments. (A) An aluminum juice can was pounded into the outcrop in an attempt to produce a good quality, undisrupted sample; however, it was difficult to extract the sample without severe disruption. (B) The best technique involved excavating large "bread-loaf" sized samples from the outcrop. (C) After exhumation, the samples were gently pried away from the outcrop. (D) The samples were immediately wrapped in several layers of plastic wrap. (E) Samples were placed in large canvas bags and duct taped prior to initial transport. $(F)$ The samples were placed in plastic bags and coated with a thin layer of epoxy prior to final transport. 


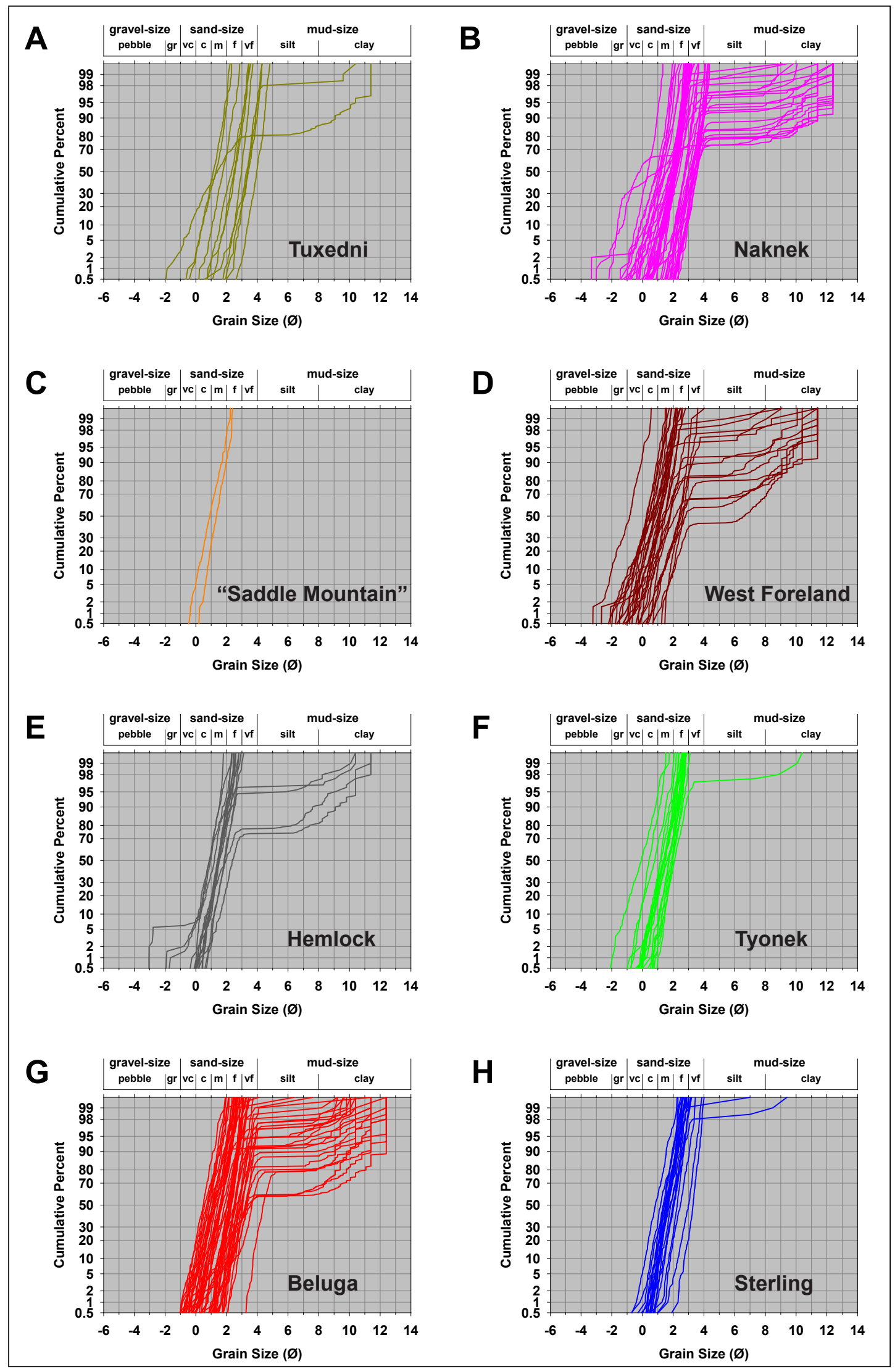

Figure 10. Cumulative probability plots of grain size by unit. Sediments with a normal (Gaussian) distribution plot as a straight line. The value of the 50th percentile indicates mean grain size, while the slope of the line indicates sorting. (A) Tuxedni Group. (B) Naknek Formation. (C) "Saddle Mountain" Sandstone. (D) West Foreland Formation. (E) Hemlock Formation. (F) Tyonek Sandstone. (G) Beluga Formation. (H) Sterling Formation. 


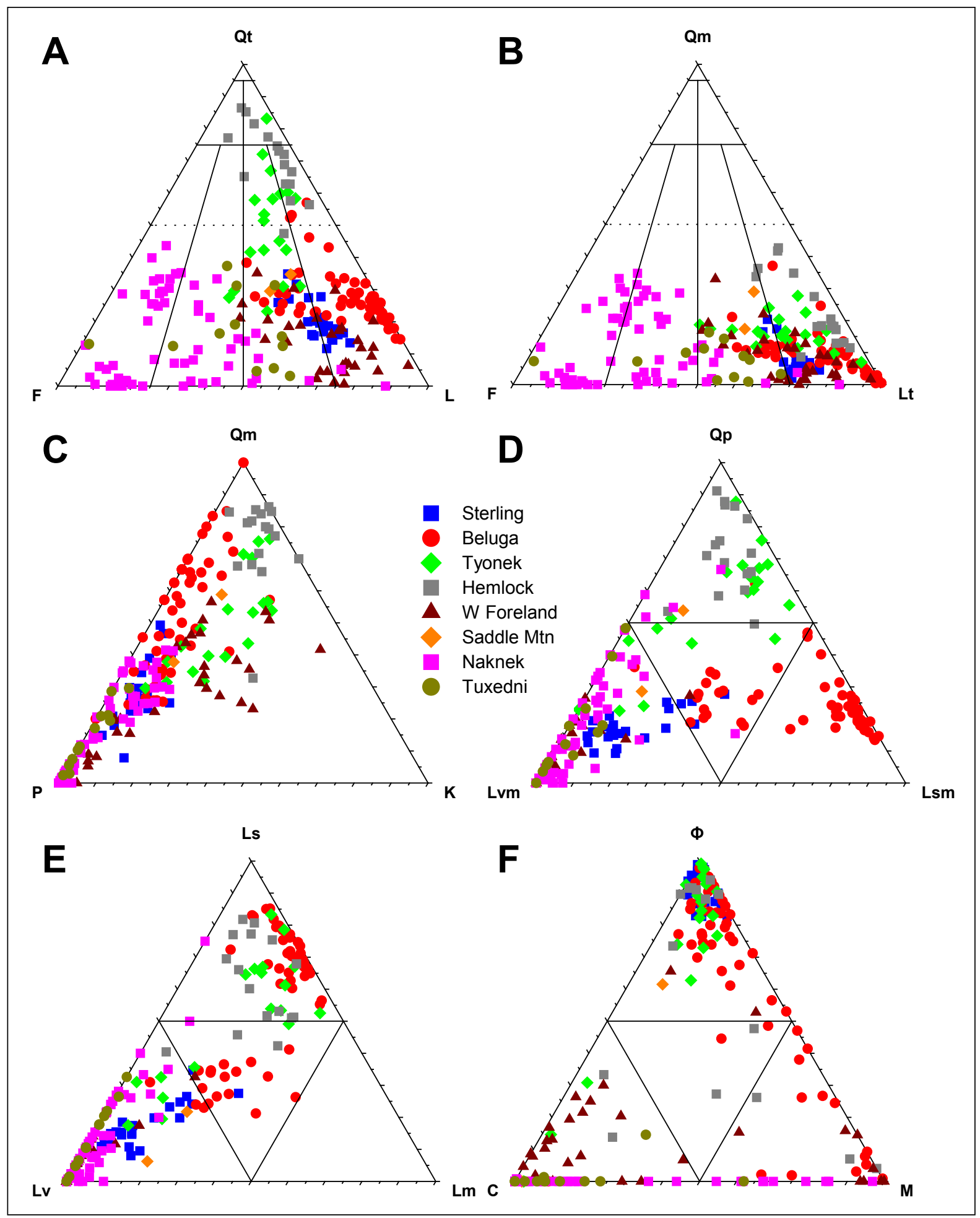

Figure 11. Ternary diagrams showing composition of Tertiary and Mesozoic sandstones. The data were obtained via the traditional point-counting method in which phaneritic rock fragments are classified as the appropriate lithology (for example, granite, diorite, gabbro, gneiss). See table 7 for explanation of grain and intergranular parameters used in the diagrams. (A) QtFL diagram; the Tyonek and Hemlock sands are the most quartzose, which is reflected in their good reservoir quality, while Naknek sands are very feldspathic. (B) QmFLt diagram; the large shift in Tyonek and Hemlock sands from A reflects their high chert content. (C) QmPK diagram; Tyonek and Hemlock sand have the lowest P/F ratios, reflecting a more "granitic" source. (D) QpLvmLsm diagram; Beluga sands are clearly distinguished by the high content of sedimentary rock fragments. (E) LsLvLm diagram; volcanic and sedimentary rock fragments are the dominant types of lithic grains. $(F)$ ФCM diagram; Sterling, Beluga, Tyonek, and Hemlock sands have significant reservoir potential; West Foreland, Naknek, and Tuxedni sands are highly cemented. 


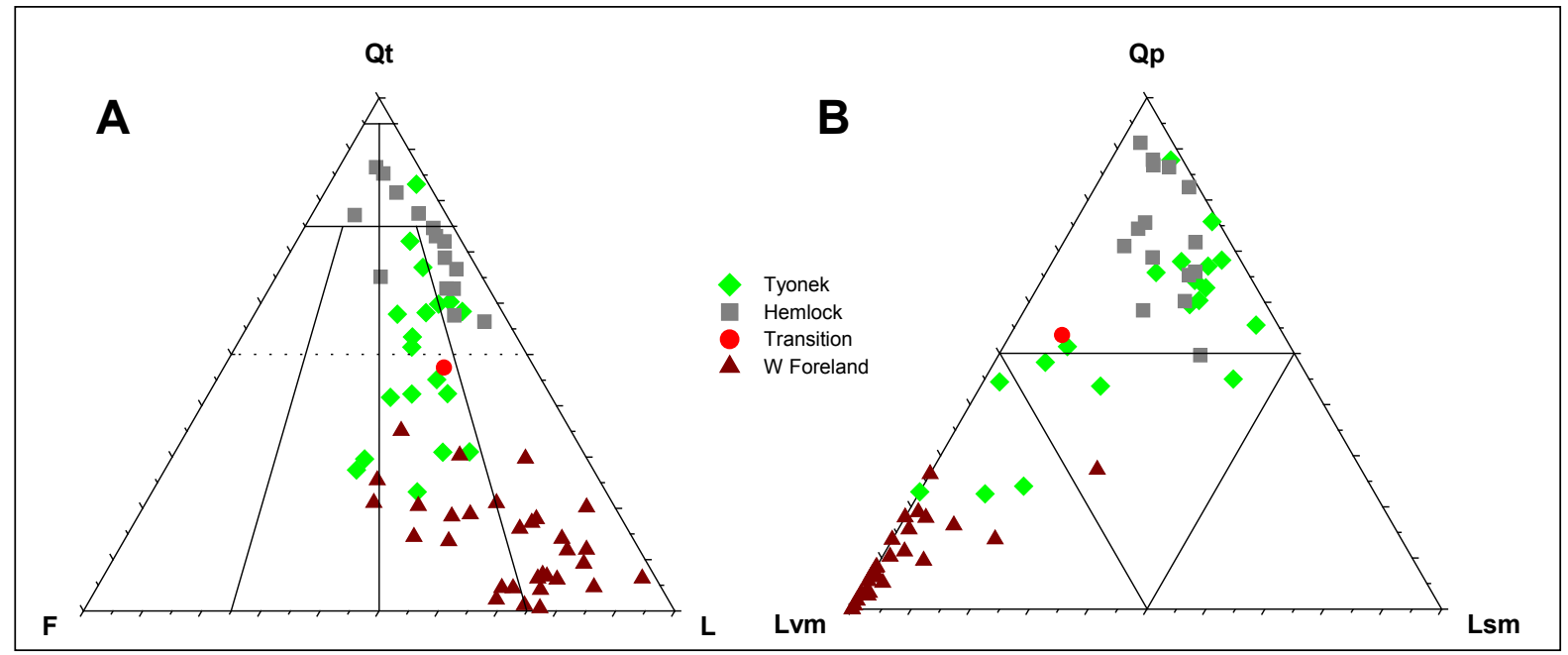

Figure 12. Ternary diagrams suggesting the West Foreland-Hemlock provenance transition. The proposed transition is based on a single sample and is, therefore, highly speculative. (A) QtFL diagram showing the change in total framework composition of the West Foreland and Hemlock sandstones. (B) QpLsmLvm diagram showing the change in composition of the lithic components of the West Foreland and Hemlock sandstones.

the 'zone of depositional control', where reservoir quality is largely controlled by textural parameters related to depositional environment. Coarser-grained sandstones deposited in high-energy settings in this zone tend overall to have better reservoir characteristics than finer-grained lithologies deposited in low-energy environments. These rocks are relatively young, have seen less burial, and consist of mixed mineralogy. The more labile sandstones in this zone are not immune from diagenetic alteration, particularly the older, more deeply buried variants. Reservoir quality of the sandstones is ultimately controlled by the complex interplay between depositional environment, mineralogy, age, and burial depth.

\section{ZONE OF DIAGENETIC CONTROL}

\section{Tuxedni Group}

Sandstones from four formations (from oldest to youngest, Red Glacier, Gaikema, Cynthia Falls, and Bowser) of the Middle Jurassic Tuxedni Group were sampled along the south shore of Tuxedni Bay and at Red Glacier (fig. 7). All the sandstones are similar in composition with an average modal composition of $\mathrm{Q}_{\mathrm{t17}} \mathrm{F}_{43} \mathrm{~L}_{40}, \mathrm{Q}_{\mathrm{m} 8} \mathrm{~F}_{44} \mathrm{~L}_{\mathrm{t} 48}$, $\mathrm{Q}_{\mathrm{m} 15} \mathrm{P}_{84} \mathrm{~K}_{1}, \mathrm{Q}_{\mathrm{p} 17} \mathrm{~L}_{\mathrm{vm} 81} \mathrm{~L}_{\mathrm{sm} 2}$ (table 4, fig. 11), and a plagioclase/feldspar $(\mathrm{P} / \mathrm{F})$ ratio of 0.98 . The average grain size is $0.20 \mathrm{~mm}$ (upper fine) with an average Folk sorting (Folk, 1974) of 0.81 (moderate; table 5, fig. 10A). Volcanic rock fragments (VRFs) are the most common framework component, consisting of both felsic and intermediate varieties with varying degrees of alteration. Plagioclase is the dominant feldspar and is typically albitized as indicated by abundant vacuoles, resulting in a brownish color in thin section (fig. 16A). The small amount of quartz is largely monocrystalline and probably of volcanic origin. Authigenic chlorite and mixed-layer chlorite/smectite are ubiquitous clay cements (figs. 16D, F), resulting in high intergranular volumes (IGVs) exceeding 30 percent. Laumontite and heulandite (zeolites) are common cements that both partially line and totally occlude intergranular pores. Zeolites and authigenic clay commonly occur together in individual pores, occluding all visible porosity (fig. 16B). Overall reservoir quality is poor (figs. 16C, E), with porosities typically less than 9 percent and permeabilities less than 1 millidarcy (fig. 15). The sandstones were derived from an undissected volcanic arc terrane (fig. 14A), most probably from volcanic flows and tuffs of the underlying Lower Jurassic Talkeetna Formation.

\section{Naknek Formation}

Sandstones of the Upper Jurassic Naknek Formation were sampled on Chisik Island, the north shore of Chinitna Bay, and along the shore of the Iniskin Peninsula (figs. 7 and 8). Naknek sandstones are conspicuously feldspathic with an average modal composition of $\mathrm{Q}_{\mathrm{t1}} \mathrm{F}_{60} \mathrm{~L}_{25}, \mathrm{Q}_{\mathrm{m} 12} \mathrm{~F}_{61} \mathrm{~L}_{\mathrm{t} 27}, \mathrm{Q}_{\mathrm{m} 16} \mathrm{P}_{81} \mathrm{~K}_{3}, \mathrm{Q}_{\mathrm{p} 17} \mathrm{~L}_{\mathrm{vm} 79} \mathrm{~L}_{\text {sm4 } 4}$ (table 4, fig. 11) and a $\mathrm{P} / \mathrm{F}$ ratio of 0.95 (Egbert, 1982, 1986; Helmold and others, 2011). The average grain size is $0.27 \mathrm{~mm}$ (lower medium) 


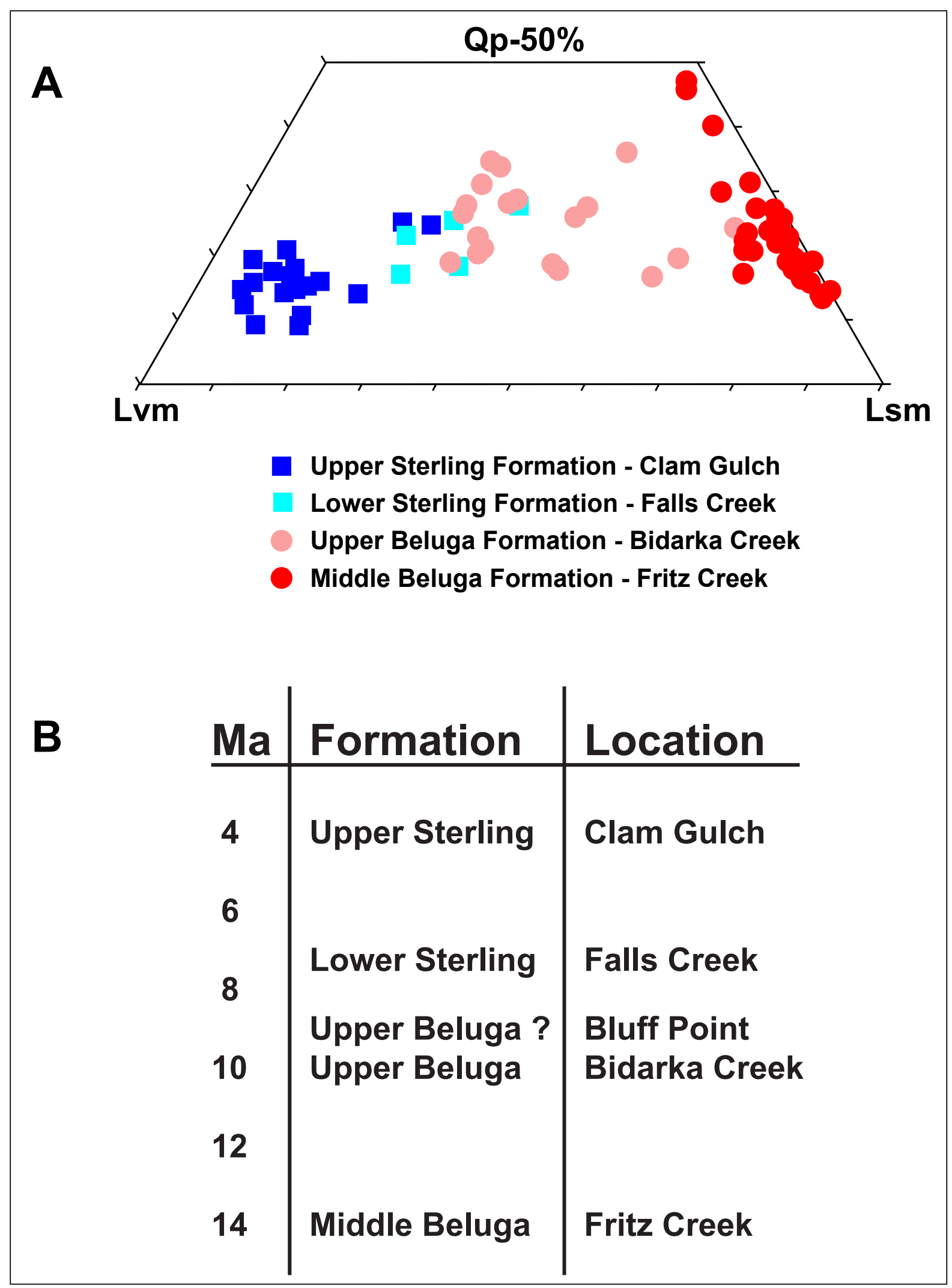

Figure 13. Diagrams documenting the Beluga-Sterling provenance transition. (A) Lower half of a QpLvmLvs diagram showing the change in composition of the Beluga and Sterling sandstones through time; see text for discussion. (B) Absolute and relative ages of Beluga and Sterling sandstones from outcrops where samples were collected. 


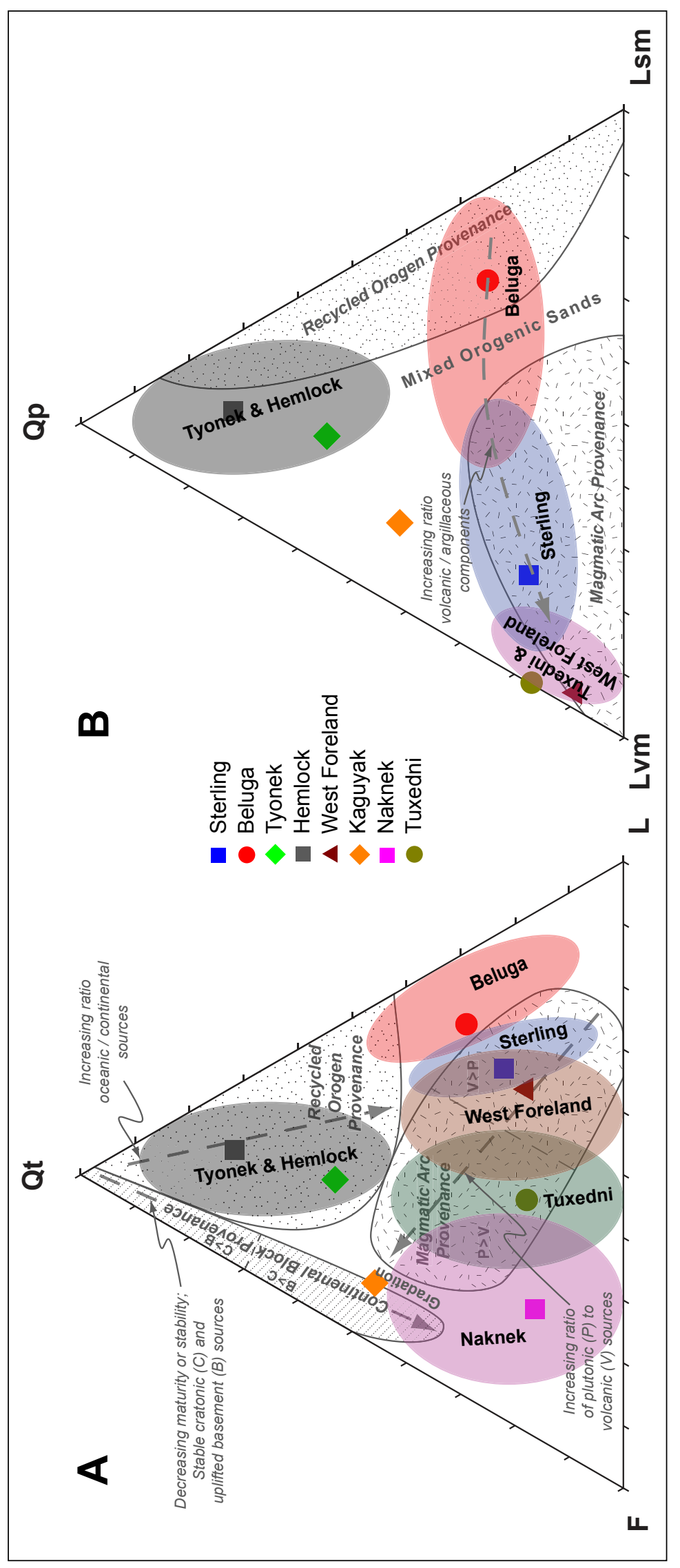

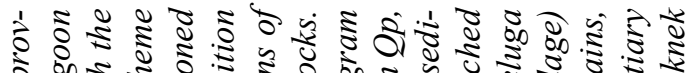

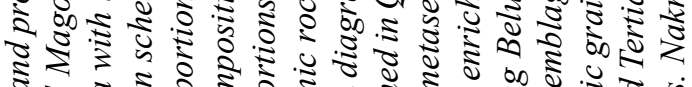

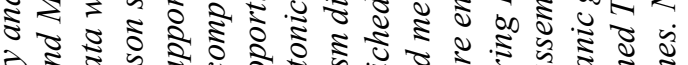

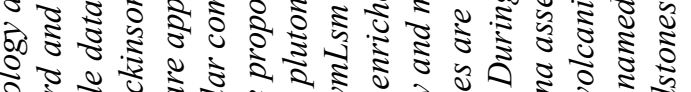

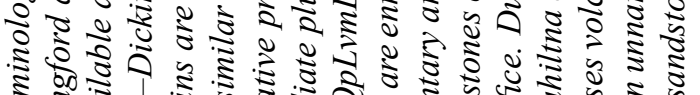

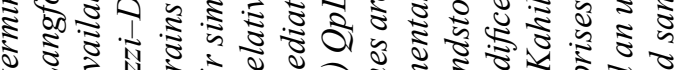

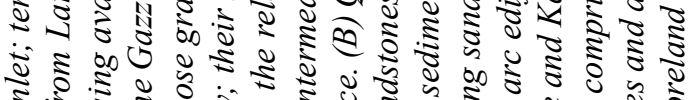
है.

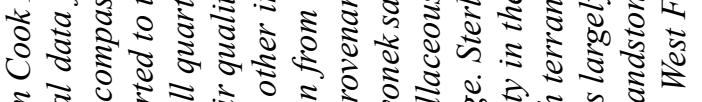

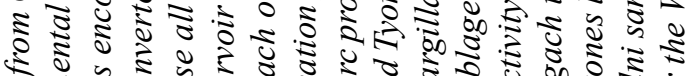

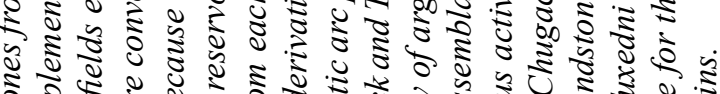

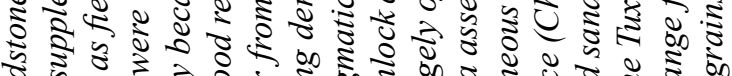

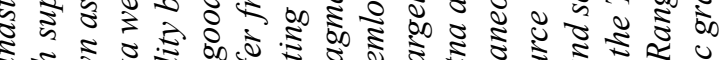

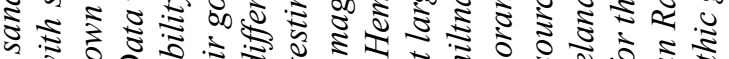

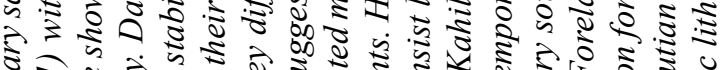

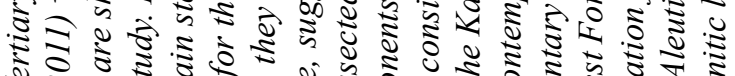
* ब ईั

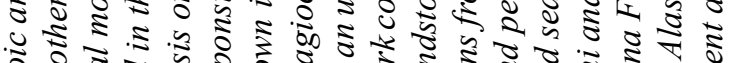

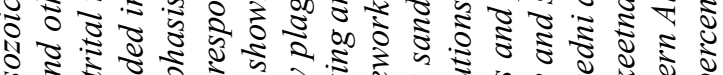
₹

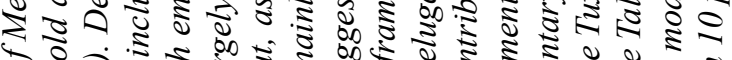
จำ.

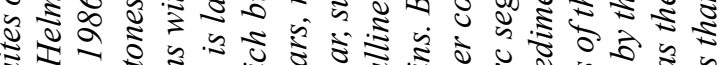

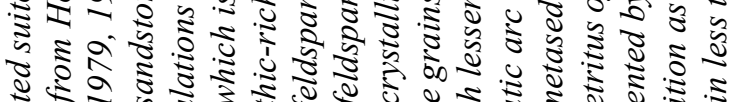

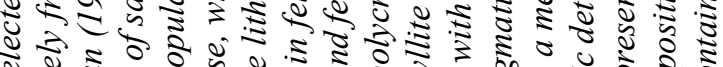

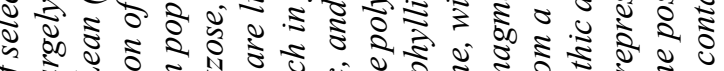

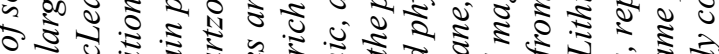

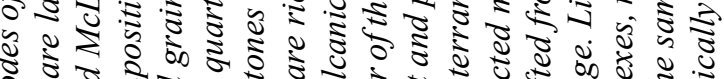

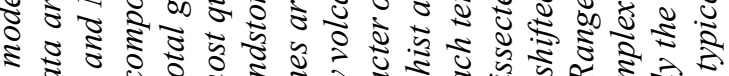

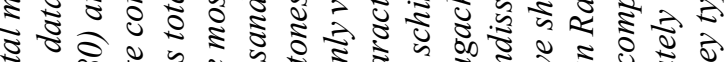

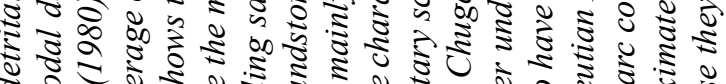
\& 8 के

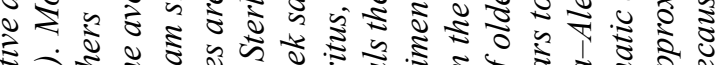

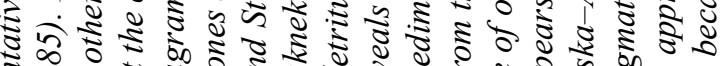

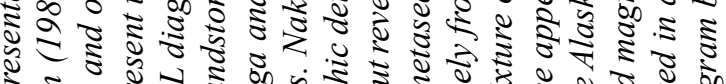

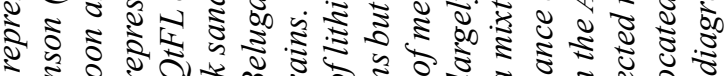

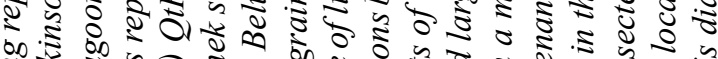

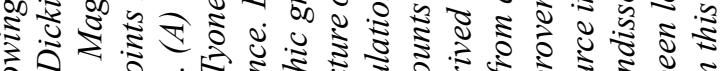

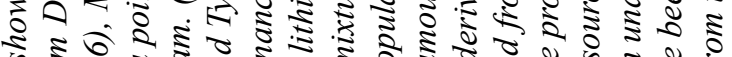

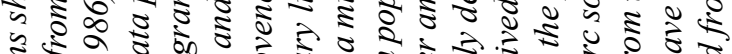

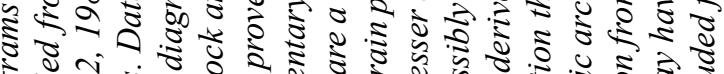

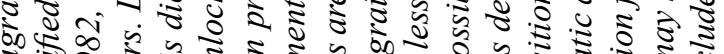

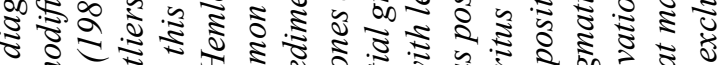
₹ ₹ हैं

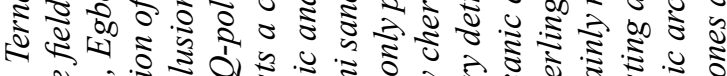

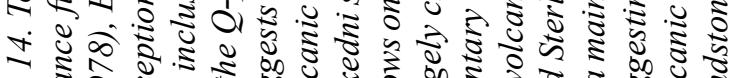

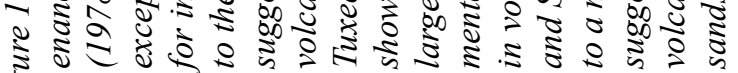
这 


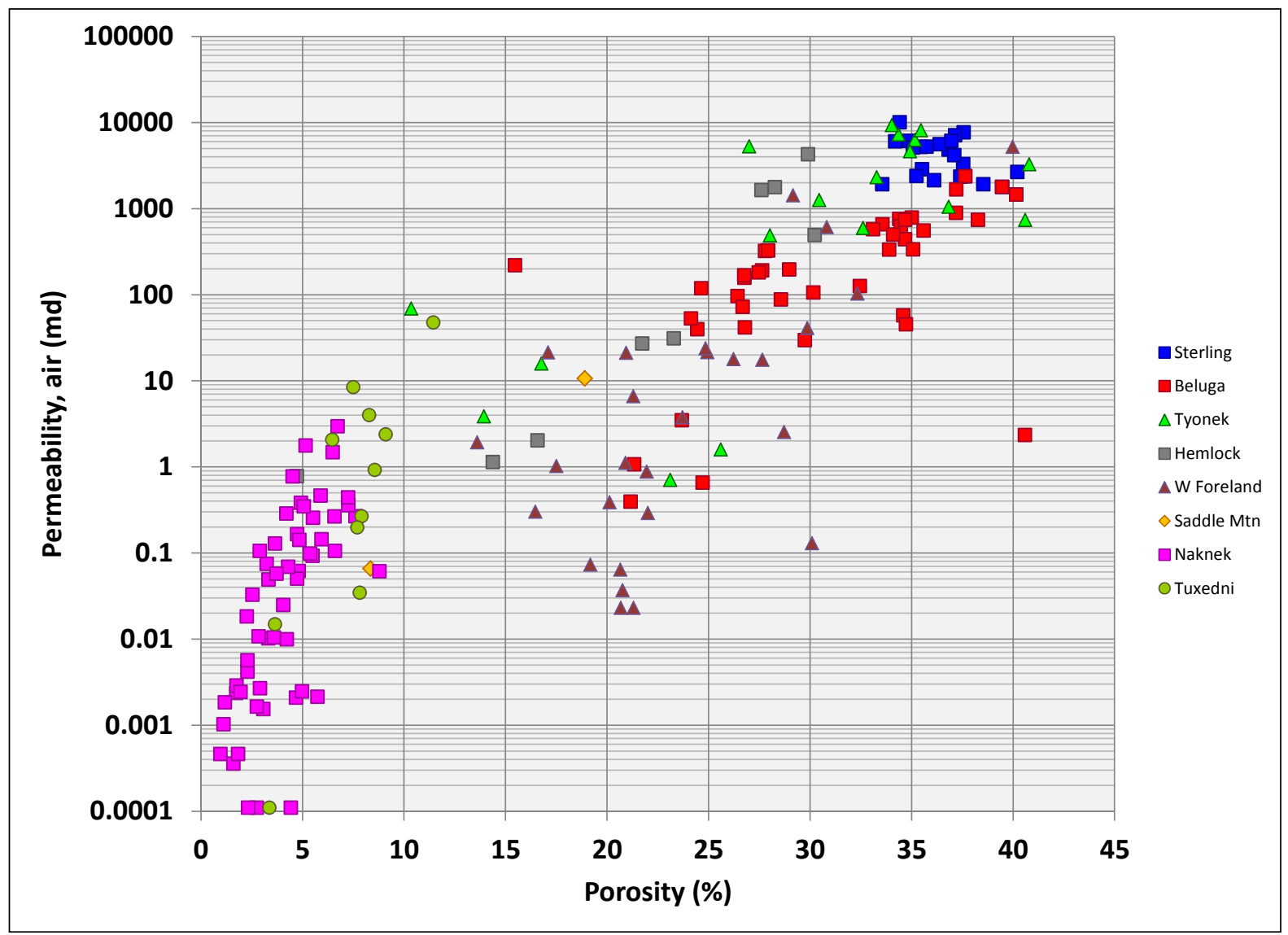

Figure 15. Porosity-permeability cross plot showing reservoir quality of Tertiary and Mesozoic sandstones included in this report. Beluga and Sterling and sandstones consistently have very good reservoir properties with high porosity and permeability, which are largely a result of their young age and shallow burial. The wide range in reservoir properties for Hemlock and Tyonek sandstones results from highly variable depositional textures. West Foreland and "Saddle Mountain" sandstones have intermediate reservoir properties. Tuxedni and Naknek sandstones consistently have poor reservoir properties with low porosity and permeability attributed to old age and labile mineralogy.

with an average Folk sorting of 1.18 (poor; table 5, fig. 10B). Calcic plagioclase is the dominant framework grain and is largely albitized and replaced by laumontite (fig. 17D). Hornblende and opaque heavy minerals (ilmenite-magnetite) are also conspicuous framework grains (fig. 17C). Laumontite cement occludes almost all residual primary porosity (fig. 17A, E), resulting in high IGVs in excess of 20 percent, suggesting that cementation occurred prior to extensive compaction. It also fills microfractures, which are fairly common. Reservoir quality is poor (fig. 17B), with porosities characteristically less than 7 percent and permeabilities less than 1 millidarcy and is, therefore, similar to that of the Tuxedni sandstones (fig. 15). Variants with greater amounts of VRFs are prone to heulandite cementation (fig. 17F). The sandstones were derived from intermediate, dissected-arc plutons (fig. 14A) with the composition of a diorite (Detterman and Hartsock, 1966).

The processes of albitization and laumontite genesis are universal in calcic plagioclase-rich samples exposed to temperatures in excess of $100^{\circ} \mathrm{C}$. There are numerous examples of similar diagenesis in arkosic sandstones throughout the circum-Pacific region (Iijima and Utada, 1971; Merino, 1975; Boles and Coombs, 1977, Boles, 1982; McCulloch, 1981; Helmold and van de Kamp, 1984). In most basins the precipitation of laumontite and albitization of sandstones are assumed to be coeval as suggested by the chemically complementary nature of the reactions (Coombs, 1954; Merino, 1975; Helmold and van de Kamp, 1984). During the initial stages of albitization, the anorthite component of plagioclase is converted to albite as an equal-volume replacement with the receipt of $\mathrm{Na}^{+}$ions from solution and the release of $\mathrm{Ca}^{+2}$ into solution (Boles, 1982; Helmold and van de Kamp, 1984): 


$$
\begin{array}{cc}
\left(\mathrm{V}_{m}=100.16\right) & \left(\mathrm{V}_{m}=100.07\right) \\
0.8 \mathrm{NaAlSi}_{3} \mathrm{O}_{8} \cdot 0.2 \mathrm{CaAl}_{2} \mathrm{Si}_{2} \mathrm{O}_{8}+0.203 \mathrm{H}_{4} \mathrm{SiO}_{4}+0.201 \mathrm{Na}^{+}+0.796 \mathrm{H}^{+}= & 1.001 \mathrm{NaAlSi}_{3} \mathrm{O}_{8}+0.2 \mathrm{Ca}^{+2}+0.199 \mathrm{Al}+3+0.804 \mathrm{H}_{2} \mathrm{O}
\end{array}
$$

At greater depths and temperatures where laumontite genesis and albitization are coeval, calcic plagioclase is partially albitized and partially replaced by laumontite (Boles and Coombs, 1977; Helmold and van de Kamp, 1984). For a given volume of plagioclase altered, an equal volume of albite-laumontite intergrowth plus additional laumontite will be produced to occlude intergranular porosity:

$$
\begin{aligned}
& \mathrm{NaAlSi}{ }_{3} \mathrm{O}_{8} \cdot \mathrm{CaAl}_{2} \mathrm{Si}_{2} \mathrm{O}_{8}+2 \mathrm{SiO}_{2}+4 \mathrm{H}_{2} \mathrm{O}=\mathrm{NaAlSi}_{3} \mathrm{O}_{8}+\mathrm{CaAl}_{2} \mathrm{Si}_{4} \mathrm{O}_{12} \cdot 4 \mathrm{H}_{2} \mathrm{O} \\
& \text { Plagioclase Quartz Albite Laumontite }
\end{aligned}
$$

In sandstones that have undergone massive replacement, an external source of $\mathrm{Na}^{+}$from solutions is necessary and is associated with the release of $\mathrm{Ca}^{+2}$ into solution (Boles and Coombs, 1977; Helmold and van de Kamp, 1984). Potential sources of the additional $\mathrm{Na}^{+}$ions include connate water and the smectite-illite transition in interbedded shales:

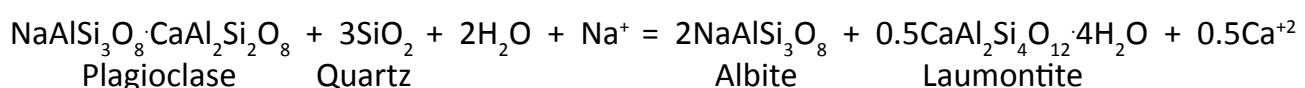

These diagenetic reactions are inevitable given the appropriate framework composition and thermal history. Successful exploration for conventional Naknek reservoirs hinges on the possibility of variation in arc composition along the length of the Aleutian-Alaska Range. As long as the plutons that source Naknek sediments have a dioritic composition, the prospects for finding conventional hydrocarbon reservoirs are minimal. If, at various locations along the volcanic arc, Naknek sandstones are sourced from more granitic plutons yielding sediments richer in quartz and $\mathrm{K}$-feldspar, the prospects for favorable reservoir quality is increased. This possibility should be addressed in future fieldwork in lower Cook Inlet. The presence of fractures, observed both in thin section and outcrop, suggests the Naknek Formation has potential as an unconventional fractured reservoir.

\section{ZONE OF DEPOSITIONAL CONTROL}

\section{Upper Cretaceous “Saddle Mountain” Sandstone}

Two samples from an unnamed Upper Cretaceous nonmarine sandstone and conglomerate succession (not formally named) were collected from the southeast flanks of Saddle Mountain between Tuxedni and Chinitna bays (reference numbers 145-146 in fig. 7). Magoon and others (1980) correlate the Saddle Mountain interval to Upper Cretaceous nonmarine strata in the COST \#1 well approximately $55 \mathrm{~km}$ to the south. Although the Upper Cretaceous interval exposed at Saddle Mountain is broadly correlative to age-equivalent marine strata of the Kaguyak Formation on the upper Alaska Peninsula as implied by Magoon and others (1980) and Hastings and others (1983), LePain and others (2012) caution against the use of formal stratigraphic terminology when referring to these strata on the grounds that no type sections for these intervals have been defined. Therefore, this unit will informally be referred to as the 'Saddle Mountain' sandstones in this report. The 'Saddle Mountain' sandstones are quartzo-feldspathic with an average modal composition of $\mathrm{Q}_{\mathrm{t32}} \mathrm{F}_{24} \mathrm{~L}_{44}, \mathrm{Q}_{\mathrm{m} 23} \mathrm{~F}_{24} \mathrm{~L}_{\mathrm{t} 53}, \mathrm{Q}_{\mathrm{m} 48} \mathrm{P}_{38} \mathrm{~K}_{14}, \mathrm{Q}_{\mathrm{p} 41} \mathrm{~L}_{\mathrm{vm} 45} \mathrm{~L}_{\mathrm{sm} 14}$ (table 4, fig. 11). The average grain size is $0.46 \mathrm{~mm}$ (upper medium) with an average Folk sorting of 0.52 (moderate; table 5, fig. 10C). Quartz is largely monocrystalline with only minor polycrystalline quartz and chert. Twinned plagioclase is the dominant feldspar with an average $\mathrm{P} / \mathrm{F}$ ratio of 0.72 . Felsic and intermediate VRFs are common, with lesser amounts of plutonic rock fragments (PRFs; fig. 18C). Reservoir quality varies from poor to moderate with the better rock having a porosity of 18.9 percent and permeability of 10.7 millidarcies (10DL011D; figs. 15, $18 \mathrm{~A}-\mathrm{C}$ ). In this sample authigenic clay occurs as thin pore linings but has only minor impact on reservoir quality. The sample with poor reservoir quality (10DL011C; figs. 18D-F) has a porosity of 8.4 percent and a permeability of 0.07 millidarcies. Pore-filling authigenic clay (fig. 18F) and calcite cement are pervasive in this sample and occlude virtually all intergranular porosity. Many framework grains are largely or totally replaced by ferroan calcite (fig. 18E).

Based on the quartzo-feldspathic mineralogy and presence of PRFs, the sandstones were probably derived from dissected arc plutons. The presence of VRFs and plagioclase suggest a secondary source from a volcanic arc terrane, most likely remnants of the Talkeetna Formation. 

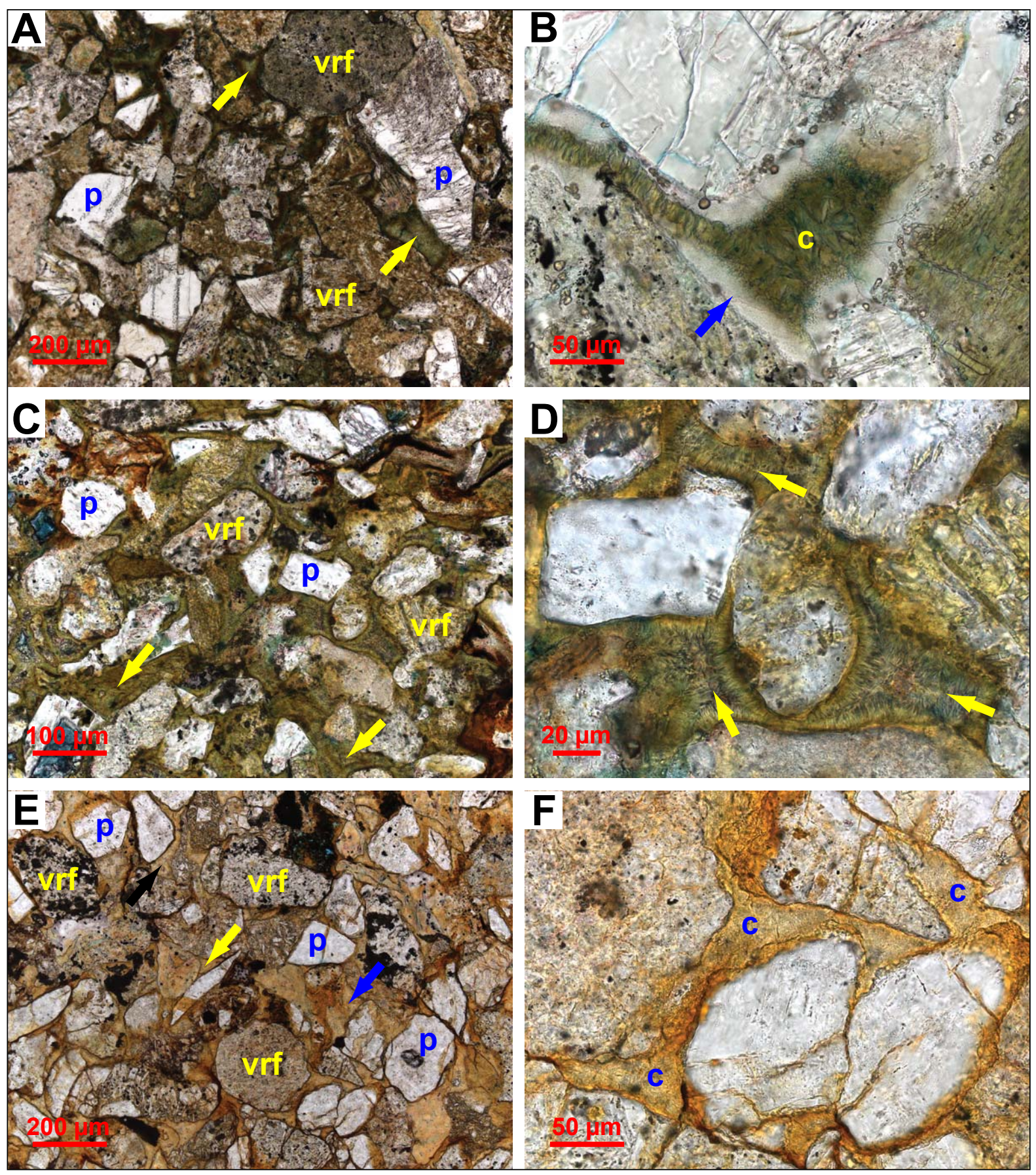

Figure 16. Photomicrographs of Tuxedni sandstones. (A) General view of Bowser sandstone showing abundance of volcanic rock fragments (vrf), plagioclase (p), and pore-filling authigenic clay (arrows) that totally occludes intergranular porosity. Sample 10DL006B. (B) Intergranular pore in Bowser sandstone lined by zeolite, probably heulandite (arrow), and filled with authigenic clay, probably chlorite (c). Sample 10DL006A. (C) General view of Red Glacier sandstone showing abundance of volcanic rock fragments (vrf), plagioclase (p), and pore-filling authigenic clay (arrows) that totally occludes intergranular porosity. Sample 09DL005-3.0. (D) Intergranular pore in Red Glacier sandstone lined by early generation of authigenic clay, probably chlorite, and filled with later generation of clay. Medial sutures (arrows) indicate an authigenic origin. Sample 09DL005-3.0. (E) General view of Gaikema sandstone showing abundance of volcanic rock fragments (vrf), plagioclase (p), and pore-filling authigenic clay (arrows) that totally occludes intergranular porosity. Sample 09DL016C (F) Intergranular pores in Gaikema sandstone filled with authigenic clay, probably chlorite (c). The presence of iron-oxides, probably limonite, formed by outcrop weathering, results in orange color. Sample 09DL016C. 

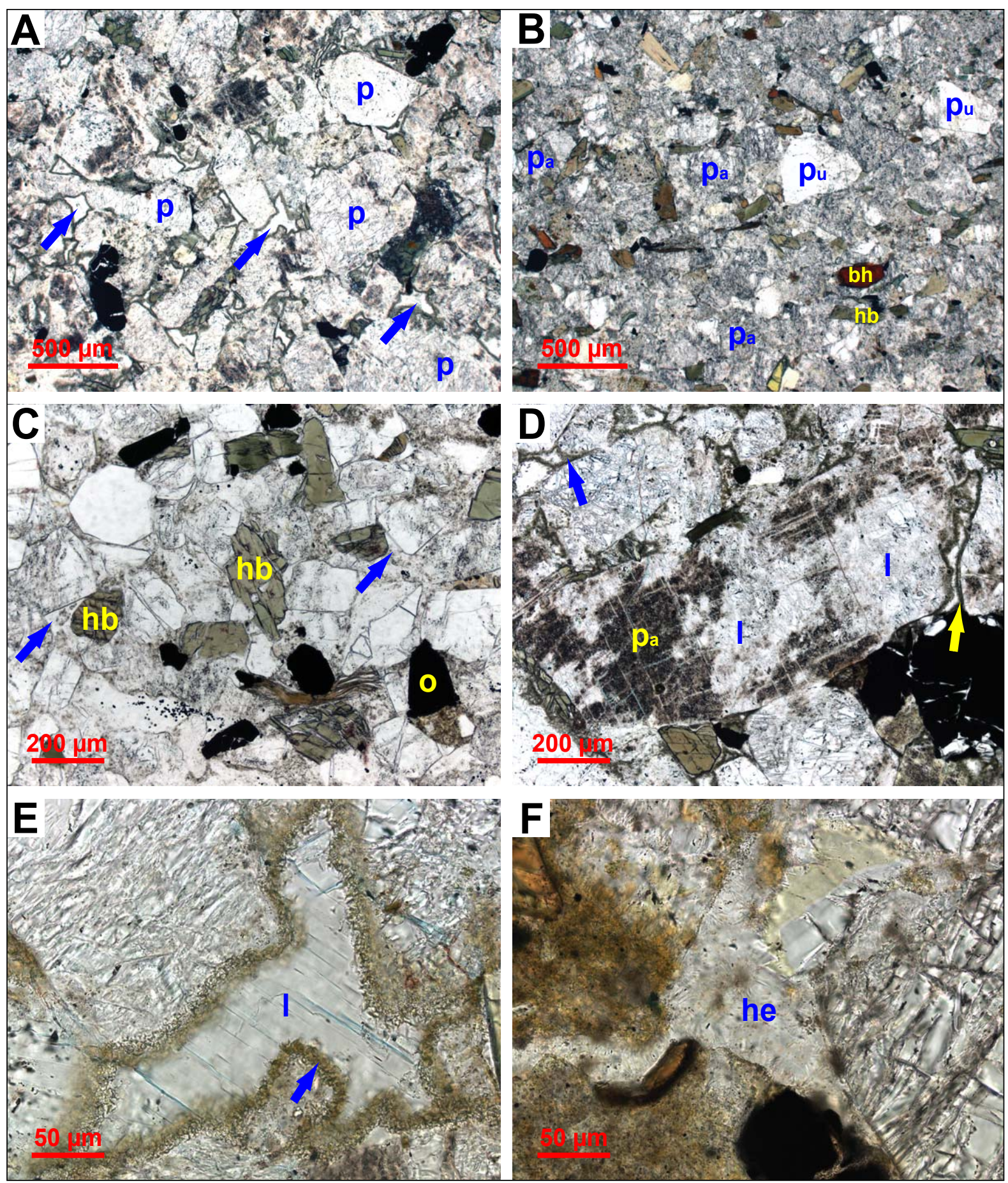

Figure 17. Photomicrographs of Naknek sandstones. (A) General view showing detrital plagioclase grains (p) and laumontite cement (arrows) totally occluding porosity. Sample 09BG005-77.0A. (B) General view showing abundant albitized plagioclase (pa) and less common unaltered plagioclase (pu). Note hornblende ( $\mathrm{hb}$ ) and basaltic hornblende (bh). Sample 10DL013A. (C) Hornblende ( $h b$ ) and opaque minerals (o), probably ilmenite or magnetite, are common accessory minerals. Intergranular pores are completely occluded by laumontite (arrows). Sample 10DL013D. (D) Detrital calcic plagioclase grain that has been albitized (pa) and partially replaced by laumontite (l). Intergranular pores are lined with authigenic clay, probably chlorite or mixed-layer chlorite/smectite (arrows), and filled with laumontite. Sample 09BG005-77.0A. (E) Intergranular pore lined with thin coat of authigenic clay, probably chlorite (arrow), and filled with later generation of laumontite (l). Sample 09BG005-77.0A. (F) Intergranular pore occluded by heulandite (he). This sample has a significant VRF content. Sample 09BG032A. 


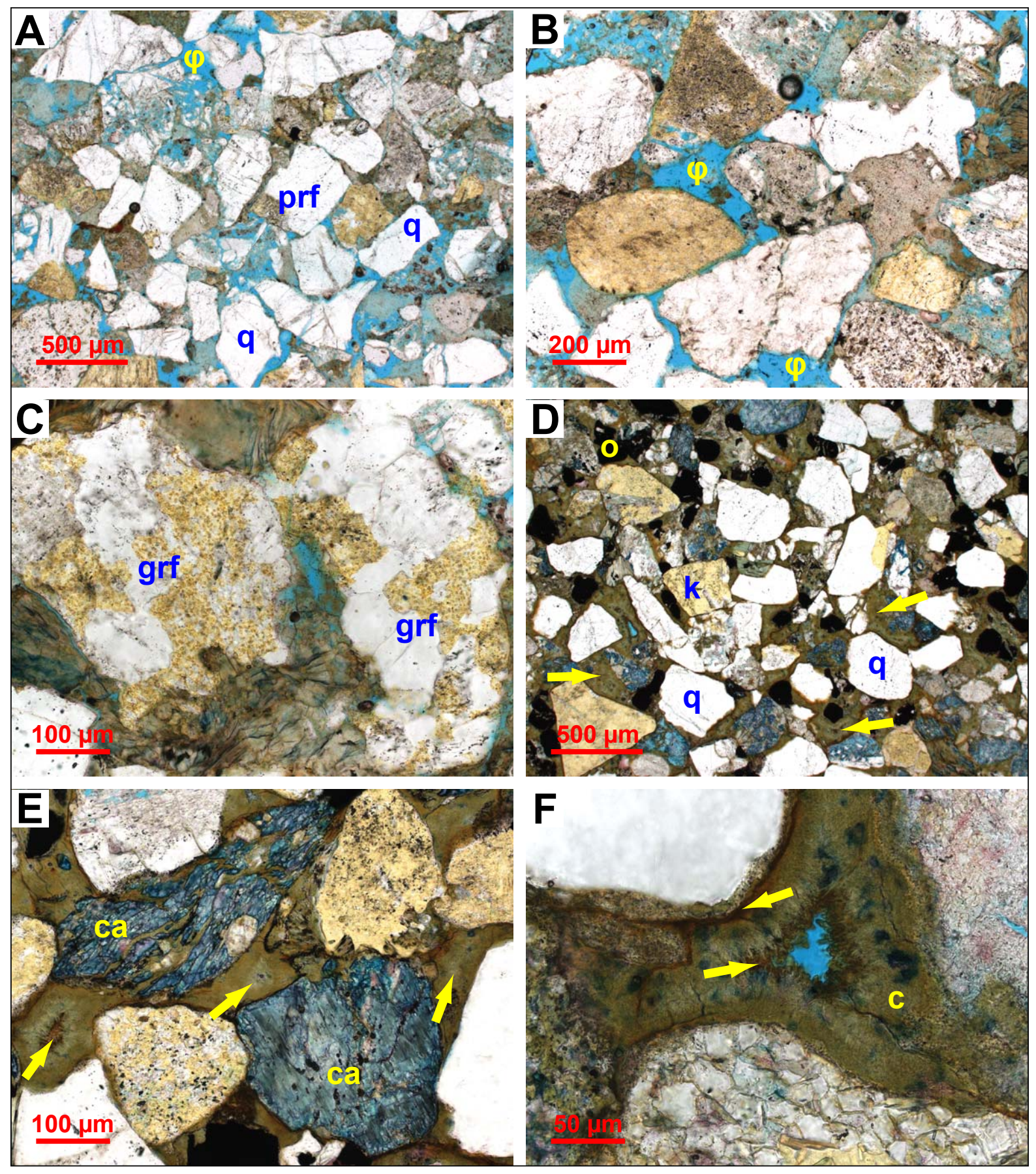

Figure 18. Photomicrographs of "Saddle Mountain" sandstones. (A) General view showing abundant quartz grains (q), plutonic rock fragments (prf), and intergranular porosity $(\varphi)$ in sample with better reservoir quality. Sample 10DL011D. (B) Angular to subangular detrital grains suggest transport distances were minimal. Intergranular porosity $(\varphi)$ suggests rock has reservoir potential. Sample 10DL011D. (C) Granitic rock fragments (grf) composed of quartz and K-feldspar are a common framework grain in "Saddle Mountain" sandstones. Sample 10DL011D. (D) General view of sample with poor reservoir quality due to extensive pore-filling clay (arrows). Note abundant rounded detrital quartz (q), K-feldspar (k), and opaque grains (o). Sample 10DL011C. (E) Ferroan calcite (ca) replacing framework grains of unknown origin. Note medial sutures in authigenic clay filling intergranular pores (arrows). Sample 10DL011C. (F) Intergranular pore partially filled by authigenic clay, probably chlorite or mixed-layer chlorite/smectite (c). Note medial sutures where inward-growing clay minerals meet in the center of the pore. The iron-bearing clay has been altered to hematite/limonite (arrows) by outcrop weathering. Sample 10DL011C. 

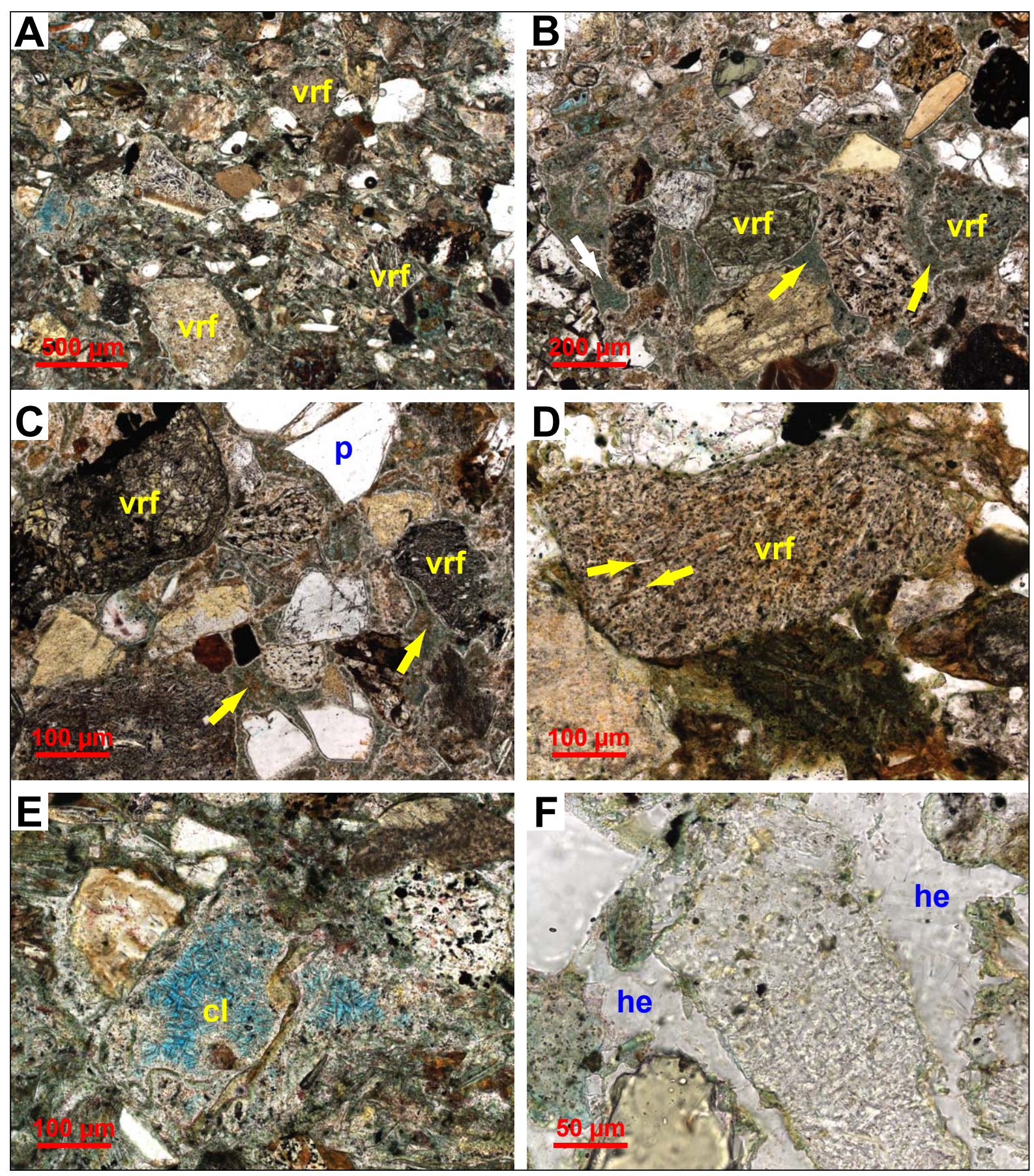

Figure 19. Photomicrographs of West Foreland sandstones. (A) General view showing abundant volcanic rock fragments (vrf) and lack of porosity. Sample 08DL056-2.9A1. (B) Authigenic clay (arrows) completely occludes intergranular porosity between volcanic rock fragments (vrf), which are the major type of framework grains. Sample 08DL056-9.0A. (C) Authigenic clay (arrows) filling intergranular pores between volcanic rock fragments (vrf) and detrital plagioclase (p). Note hints of microporosity (faint blue) in the clay. Sample 08DL056-9.0A. (D) Microlitic volcanic rock fragment (vrf) showing subtle alignment of plagioclase laths (arrows). Sample 08DL053-24.4A. (E) Zeolite, probably clinoptilolite (cl), filling secondary void created by dissolution of framework grain, probably a VRF. Sample 08DL056-2.9A1. (F) Zeolite, probably heulandite (he), completely filling intergranular pores. Sample 08DL053-22.3A. 


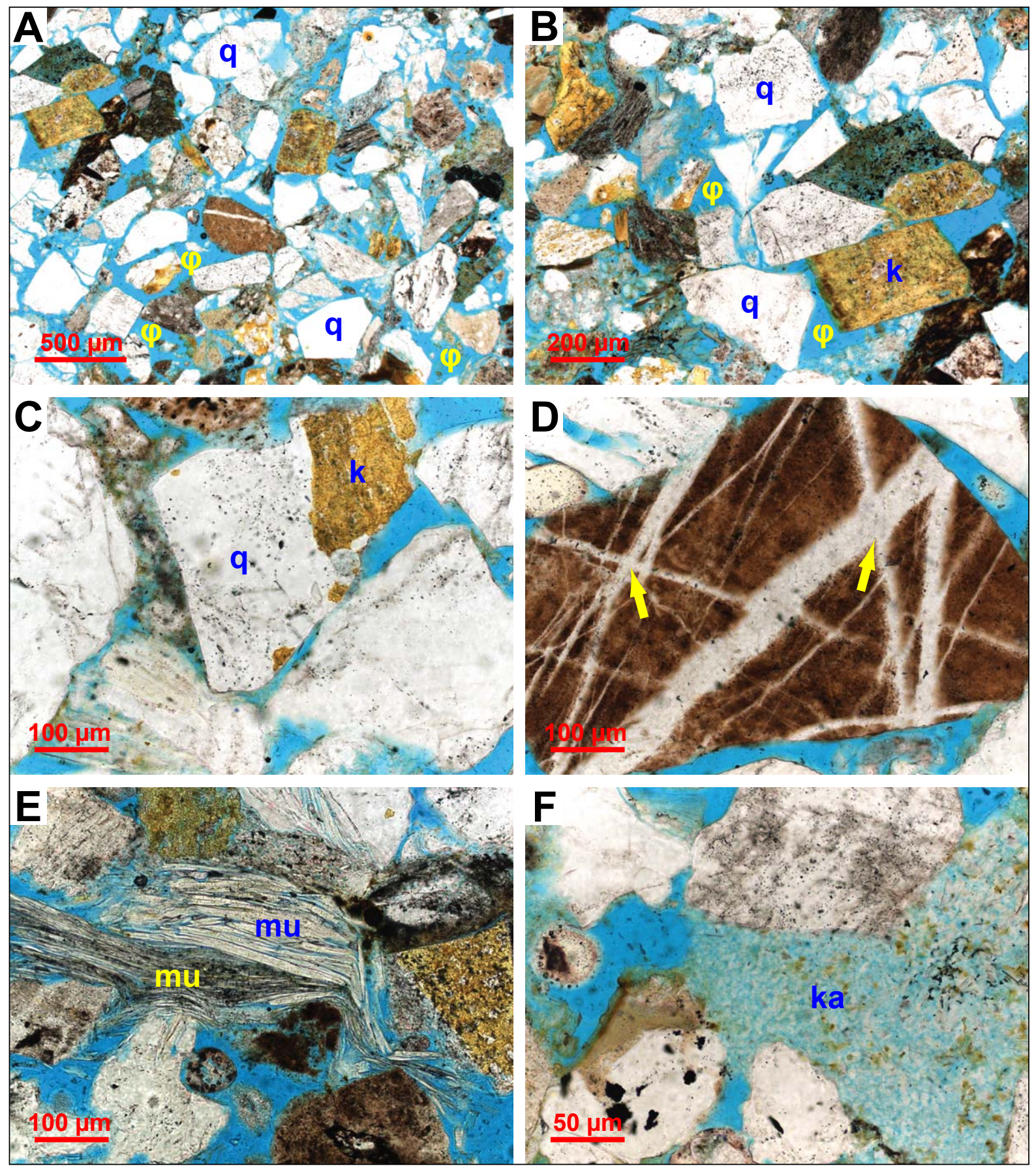

Figure 20. Photomicrographs of Hemlock sandstones. (A) General view showing abundance of quartzose grains $(q)$ and intergranular porosity $(\varphi)$. Sample 07DL073-1.1A. (B) Quartz $(q)$ and K-feldspar $(k)$ are common framework grains. Note abundance of intergranular pores $(\varphi)$ with open pore throats. Sample 07DL073-1.1A. (C) Granitic rock fragment consisting of quartz (q) and K-feldspar (k). Surrounding grains are monocrystalline quartz. Sample 07DL073-1.5A. (D) Argillaceous chert grain with several crisscrossing quartz veins (arrows). Sample 07DL073-1.5A. (E) Detrital muscovite grains (mu) that have been deformed by ductile grain deformation; this process aids in porosity destruction. Sample 07DL073-1.1A. (F) Intergranular pore partially filled by kaolinite (ka), which is a byproduct of feldspar alteration and dissolution. Sample 07DL073-1.5A. 


\section{West Foreland Formation}

Sandstones of the Eocene West Foreland Formation were sampled between Straight Creek and Capps Glacier in the Tyonek Quadrangle (fig. 6). West Foreland sandstones are distinctly volcaniclastic with an average modal composition of $\mathrm{Q}_{\mathrm{t} 14} \mathrm{~F}_{21} \mathrm{~L}_{65}, \mathrm{Q}_{\mathrm{m} 9} \mathrm{~F}_{21} \mathrm{~L}_{\mathrm{t} 70}, \mathrm{Q}_{\mathrm{m} 28} \mathrm{P}_{55} \mathrm{~K}_{17}, \mathrm{Q}_{\mathrm{p} 9} \mathrm{~L}_{\mathrm{vm} 88} \mathrm{~L}_{\mathrm{sm} 3}$ (table 4, fig. 11) and a $\mathrm{P} / \mathrm{F}$ ratio of 0.73 (Helmold and others, 2011). The average grain size is $0.45 \mathrm{~mm}$ (upper medium) with an average Folk sorting of 1.41 (poor; table 5, fig. 10D). VRFs are the dominant framework component and vary in composition from abundant felsic varieties to less common mafic variants (figs. 19A, B). Plagioclase is the dominant feldspar with varying degrees of alteration and locally extensive zoning. Monocrystalline quartz is a minor component and is most likely of volcanic origin as suggested by the dearth of inclusions and straight extinction. Hornblende, basaltic hornblende, pumice, and glass shards are accessory components (figs. 19C, D). Authigenic pore-lining and pore-filling clay is common to abundant in most samples, averaging higher than 17 percent of the bulk rock. Based on optical properties, it is probably chlorite and/or mixed-layer chlorite/smectite, but X-ray diffraction analyses are needed for positive identification. Zeolites (heulandite and clinoptilolite) are fairly common as both pore-filling cement and alteration of VRFs (figs. 19E, F). As a result of the labile mineralogy, reservoir quality is moderate to poor in most samples, with porosities ranging from 13 to 30 percent and permeabilities of $0.2-40 \mathrm{md}$ (fig. 15). The higher end of the porosity range probably reflects samples with significant ineffective microporosity. The vast majority of West Foreland thins sections examined have little macroporosity.

The abundance of VRFs, including pumice, and plagioclase suggest derivation from an undissected volcanic arc terrane; many sandstones are tuffaceous and record coeval explosive volcanism. Interbedded conglomerates of the West Foreland Formation contain a significant proportion of granitoid clasts in addition to a variety of volcanic clasts, suggesting derivation from a dissected arc provenance. Taken together, the sandstones and conglomerates are probably derived from a mixed provenance including both undissected and dissected arc segments.

\section{Hemlock Formation}

Sandstones of Oligocene age that are tentatively mapped as Hemlock Conglomerate were sampled along the upper reaches of the Chuitna River and along the Beluga River (fig. 5). Hemlock sandstones are fairly quartzose with an average modal composition of $\mathrm{Q}_{\mathrm{t} 70} \mathrm{~F}_{7} \mathrm{~L}_{23}, \mathrm{Q}_{\mathrm{m} 23} \mathrm{~F}_{8} \mathrm{~L}_{\mathrm{t} 69}, \mathrm{Q}_{\mathrm{m} 75} \mathrm{P}_{8} \mathrm{~K}_{17}, \mathrm{Q}_{\mathrm{p} 72} \mathrm{~L}_{\mathrm{vm} 12} \mathrm{~L}_{\text {sm16 }}$ (table 4, fig. 11; Helmold and others, 2011). The average grain size is $0.35 \mathrm{~mm}$ (lower medium) with an average Folk sorting of 1.03 (poor; table 5, fig. 10E). Monocrystalline quartz is the dominant framework grain (fig. 20A) with roughly equal amounts of polycrystalline quartz and chert (fig. 20D), hence the $\mathrm{C} / \mathrm{Q}_{\mathrm{t}}$ ratio $=0.31$ (table 4 ). K-feldspar (predominantly orthoclase) is more abundant than plagioclase with an average $\mathrm{P} / \mathrm{F}$ ratio of 0.29 . The $\mathrm{K}$-feldspar is relatively fresh (fig. 20B), while plagioclase has undergone extensive alteration and dissolution. Lithic fragments consist of felsic to intermediate VRFs, tuff, quartz-mica schist, phyllite, mudstone, argillite, and granitic rock fragments (fig. 20C). Detrital mica, particularly muscovite, is common and usually has undergone ductile grain deformation (fig. 20E). Reservoir quality is moderate to very good and these sandstones comprise reservoirs in many of the Cook Inlet oil fields with an average porosity in excess of 20 percent and an average permeability approaching one darcy (table 6, fig. 15). Pore-filling kaolinite resulting from feldspar alteration is locally abundant and has a detrimental effect on reservoir quality, particularly permeability (fig. 20F).

These sandstones probably have a mixed provenance. Their quartzose nature suggests possible sediment input from a collisional orogen north and west of Cook Inlet basin, perhaps the Kahiltna assemblage and/or recycling of pre-Oligocene Cenozoic sandstones in the Matanuska Valley (Hampton and others, 2007; Kalbas and others, 2007; Trop and Ridgway, 2007). The quartzo-feldspathic mineralogy with a low P/F ratio also suggests input from dissected arc plutons of the Alaska-Aleutian Range in which granite, granodiorite, and tonalite were the dominant lithologies. The presence of volcanic and metamorphic rock fragments indicates supracrustal rocks were associated with the plutons. Minor tuffaceous material suggests volcanism was contemporaneous with sandstone deposition but at a much reduced level compared to the West Foreland Formation.

\section{Tyonek Formation}

Sandstones of the lower to middle Miocene Tyonek Formation were sampled at Capps Glacier and along the Chuitna and Beluga Rivers (figs. 5 and 6). Tyonek sandstones have an average modal composition of $\mathrm{Q}_{t 49} \mathrm{~F}_{19} \mathrm{~L}_{32}$, $\mathrm{Q}_{\mathrm{m} 16} \mathrm{~F}_{19} \mathrm{~L}_{\mathrm{t} 65}, \mathrm{Q}_{\mathrm{m} 50} \mathrm{P}_{30} \mathrm{~K}_{20}, \mathrm{Q}_{\mathrm{p} 54} \mathrm{~L}_{\mathrm{vm} 25} \mathrm{~L}_{\mathrm{sm} 21}$, (table 4, fig. 11; Helmold and others, 2011) and probably share a common provenance with the Hemlock sandstones. The average grain size is $0.41 \mathrm{~mm}$ (upper medium) with an average Folk sorting of 0.58 (medium; table 5, fig. 10F). Monocrystalline quartz, polycrystalline quartz, and chert occur in roughly equal proportions, yielding a $\mathrm{C} / \mathrm{Q}_{\mathrm{t}}$ ratio of 0.30 (table 4 ). Together they comprise the dominant type 


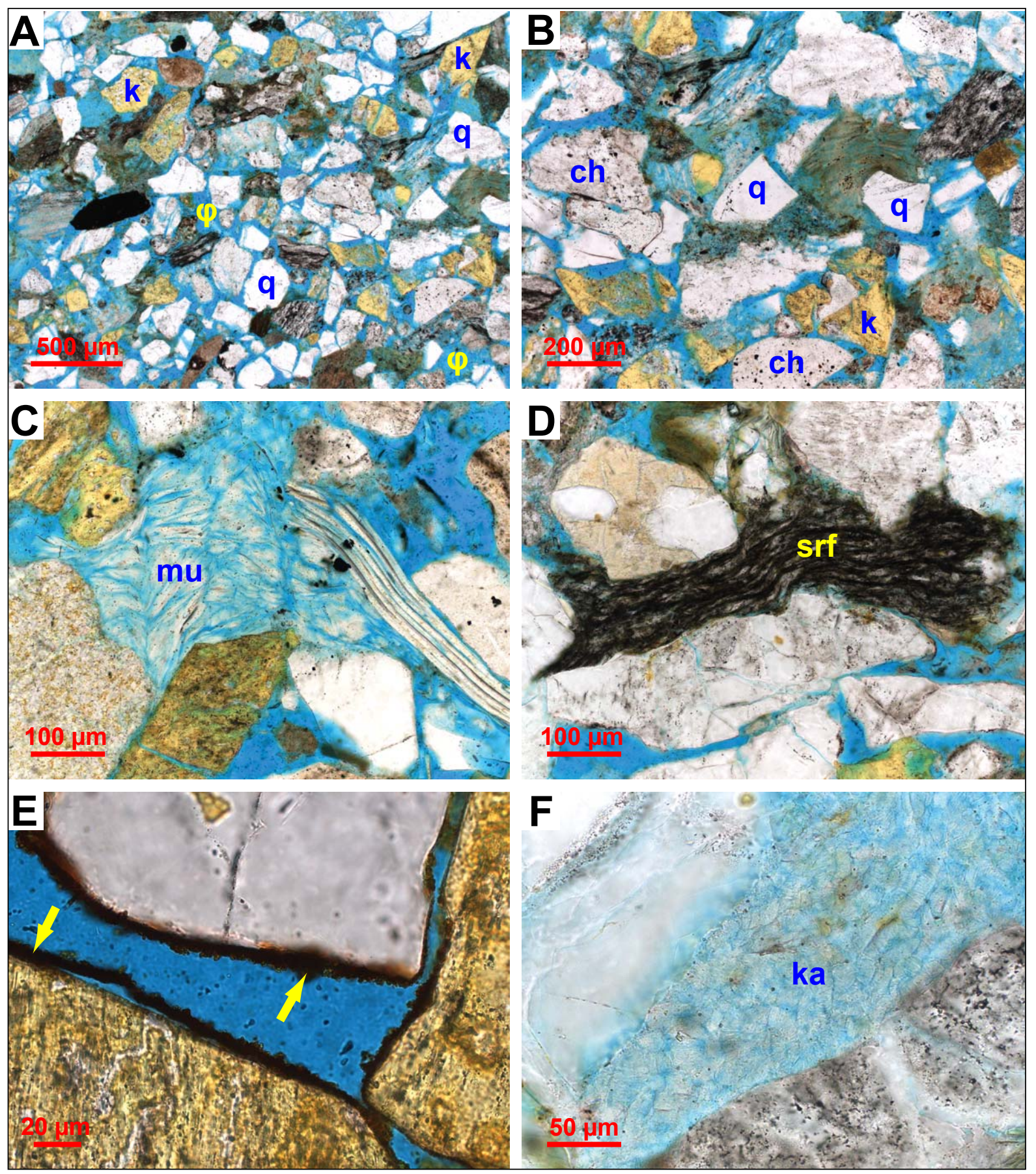

Figure 21. Photomicrographs of Tyonek sandstones. (A) General view showing abundance of quartz (q), K-feldspar $(k)$, and intergranular porosity $(\varphi)$. Sample 08DL005-8.6A. (B) Abundant intergranular pores with open pore throats are an indication of good reservoir quality. Note abundant quartz (q), chert (ch), and K-feldspar ( $k$ ) grains. Sample 08DL055-8.6A. (C) Extensively deformed detrital muscovite grain (mu) with microporosity between cleavage planes. Sample 08DL055-8.6A. (D) Moderately deformed argillaceous sedimentary rock fragment (srf) showing alignment of platy clay grains (fissility). Sample 09DL033-1.6A. (E) Pore-lining authigenic clay (arrows) that is probably chlorite or mixed-layer chlorite/smectite. The reddish-brown color of the clay is caused by hematite/limonite staining resulting from outcrop weathering. Sample 08DL050-3.2B. (F) Booklets of authigenic kaolinite $(\mathrm{ka}$ ) filling large secondary pore, probably resulting from dissolution of framework grain. Sample 09DL033-1.6A. 
of framework grain (figs. 21 A, B). Plagioclase and K-feldspar (predominantly orthoclase) are present in roughly equal proportions with an average $\mathrm{P} / \mathrm{F}$ ratio of 0.56 . Similar to Hemlock sandstones, K-feldspar is relatively fresh, while plagioclase has undergone extensive alteration and dissolution. Major lithic fragments include felsic to intermediate VRFs, tuff, quartz-mica schist, phyllite, mudstone (fig. 21D), argillite, and granitic rock fragments. Detrital muscovite is a minor accessory mineral and is commonly deformed by ductile grain deformation (fig. 21C). Reservoir quality is good to excellent with an average porosity of nearly 30 percent and permeability approaching 3 darcies (table 6, fig. 15). These sandstones are proven reservoirs, comprising the main reservoir in many of the oil fields in Cook Inlet. Pore-filling kaolinite is a common alteration of feldspars and locally completely occludes intergranular pores and replaces entire grains (fig. 21F). Pore-lining clay (probably chlorite or mixed-layer chlorite/ smectite) is common in some samples (fig. 21E). Although it has little effect on porosity it does impact permeability, particularly in those samples in which pore throats are obstructed. Like the Hemlock sandstones, these sandstones have a mixed provenance.

The quartzose nature of the sandstones suggests sediment derivation from a collisional orogen, perhaps the Kahiltna assemblage (Hampton and others, 2007; Kalbas and others, 2007) and/or uplifted Paleocene and Eocene strata in the Matanuska Valley (Trop and Ridgway, 2007). Secondary input from dissected arc plutons in which granite, granodiorite, and tonalite were the dominant lithologies is suggested by the quartzo-feldspathic mineralogy. Sediments were also derived from supracrustal rocks of the arc edifice as indicated by the presence of VRFs and MRFs. Volcanism contemporaneous with sandstone deposition is suggested by the presence of tuffaceous fragments.

\section{Beluga Formation}

Sandstones of the middle to upper Miocene Beluga Formation were sampled along the west shore of Kachemak Bay, east bank of the Beluga River, and north bank of the Chuitna River (figs. 3 and 5). Beluga sandstones are enriched in argillaceous sedimentary and metasedimentary detritus with an average modal composition of $\mathrm{Q}_{128} \mathrm{~F}_{10} \mathrm{~L}_{62}$, $\mathrm{Q}_{\mathrm{m} 8} \mathrm{~F}_{10} \mathrm{~L}_{\mathrm{t} 82}, \mathrm{Q}_{\mathrm{m} 53} \mathrm{P}_{40} \mathrm{~K}_{7}, \mathrm{Q}_{\mathrm{p} 25} \mathrm{~L}_{\mathrm{vm} 15} \mathrm{~L}_{\text {sm60 }}$ (table 4, fig. 11). The average grain size is $0.26 \mathrm{~mm}$ (lower medium) with an average Folk sorting of 1.27 (poor; table 5, fig. 10G). The sandstones are composed largely of argillaceous lithic grains including mudstone (fig. 22E), siltstone (fig. 22D), argillite, and phyllite, resulting in high structural-clay content. Quartz, feldspar, and chert (fig. 22F) are minor components of the rocks, together composing less than one-quarter of the framework fraction. IGVs average 22 percent, indicating the rocks have undergone moderate compaction (figs. $22 \mathrm{~A}, \mathrm{~B}$ ). The Beluga sands are one of the main gas reservoirs in Cook Inlet, with typical porosities in excess of 25 percent and permeabilities of several hundred millidarcies (fig. 15). The effective porosity of the rocks may be significantly lower than the measured values due to the prevalence of microporosity in the argillaceous lithic fragments. Because of the small pore throats associated with the micropores, the migration of liquids, particularly liquid hydrocarbons, may be retarded. Cementation is not significant, with total cements averaging less than 2 percent of the bulk rock. Due to high clay content, they are readily susceptible to ductile grain deformation (figs. 22B, C).

The sands were most likely derived from sedimentary and metasedimentary rocks of Mesozoic age in the Chugach terrane southeast of Cook Inlet basin, with additional contributions from the Kahiltna assemblage north and west of the Cook Inlet basin. Due to the ambiguities of identifying mudstones via standard petrographic techniques, it is difficult to assess the extent of contributions from the two sources.

\section{Sterling Formation}

Upper Miocene and Pliocene Sterling Formation sandstones were sampled at Clam Gulch, along the Beluga River, and along the west shore of Kachemak Bay (figs. 3-5). Sterling sandstones do not have a uniform composition throughout the stratigraphic sections studied. The transition in provenance from the middle Beluga through the upper Sterling Formations is discussed at length in a later section. In general, Sterling sandstones are volcanogenic with an average modal composition of $\mathrm{Q}_{\mathrm{t} 20} \mathrm{~F}_{20} \mathrm{~L}_{60}, \mathrm{Q}_{\mathrm{m} 8} \mathrm{~F}_{20} \mathrm{~L}_{\mathrm{t} 72}, \mathrm{Q}_{\mathrm{m} 28} \mathrm{P}_{64} \mathrm{~K}_{8}, \mathrm{Q}_{\mathrm{p} 18} \mathrm{~L}_{\mathrm{vm} 65} \mathrm{~L}_{\text {sm17 }}$ (table 4, fig. 11) and a $\mathrm{P} / \mathrm{F}$ ratio of 0.89 . The average grain size is $0.31 \mathrm{~mm}$ (lower medium) with an average Folk sorting of 0.55 (moderate; table 5, fig. 10H). Felsic and intermediate VRFs are the dominant type of framework grain (fig. 23A) and show relatively little alteration. Pumiceous (figs. 23B, C) and vitrophyric (figs. 23D, E) grains are common, as are hornblende and basaltic hornblende, which are relatively fresh, showing little alteration or dissolution (fig. 23F). Twinned plagioclase is the dominant feldspar and is largely unaltered; $\mathrm{K}$-feldspar is a minor component. Monocrystalline quartz is a minor framework component and is probably of volcanic origin as indicated by its water-clear, relatively unstrained character and occasional straight sides. The IGV is slightly more than 30 percent, indicating the rocks have not undergone significant compaction. Cements average less than 1 percent of the bulk 

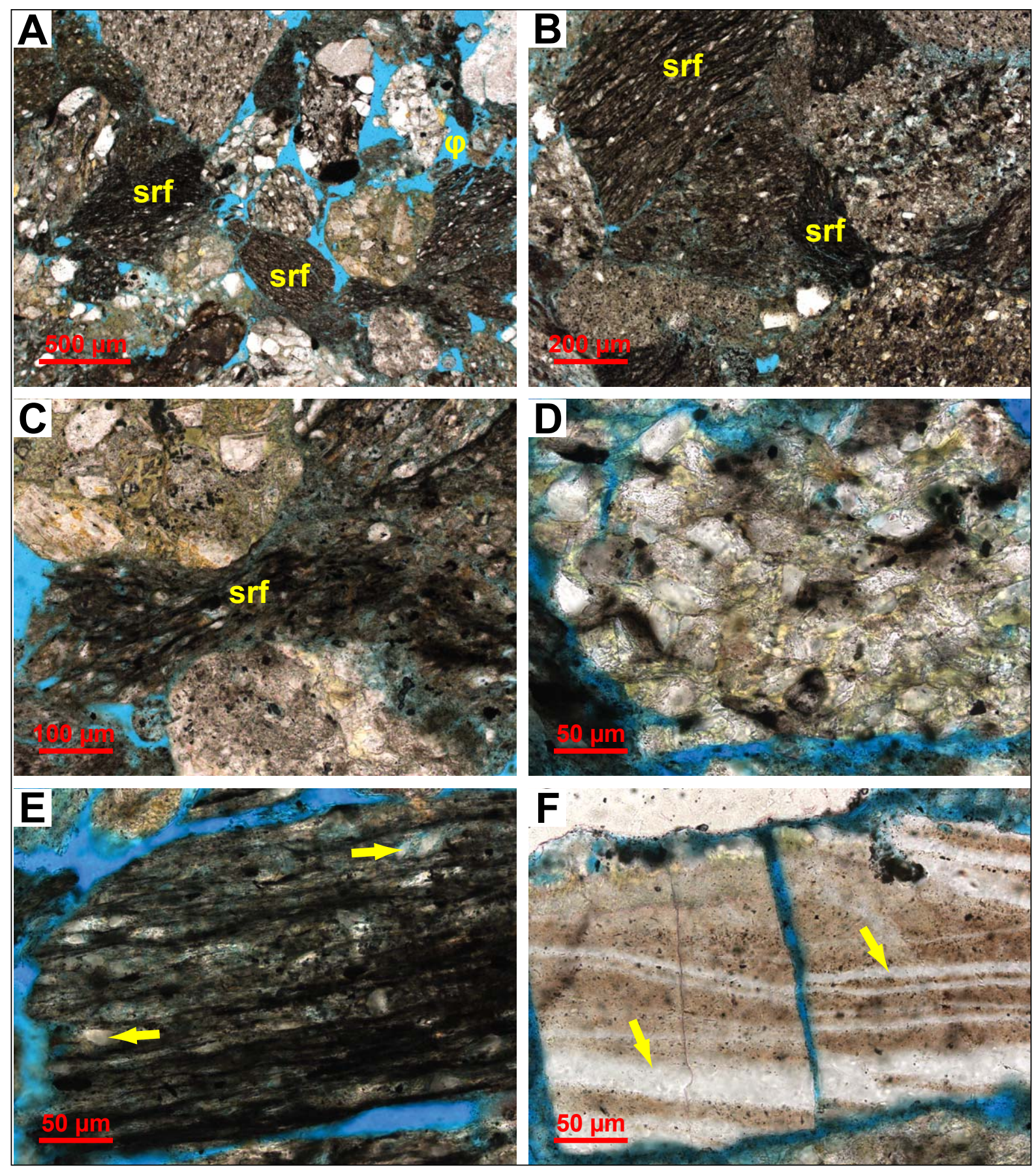

Figure 22. Photomicrographs of Beluga sandstones. (A) General view showing abundant argillaceous sedimentary rock fragments (srf), which are the dominant type of framework grain. Note intergranular porosity $(\varphi)$. Sample 07JRM002-7.0A. (B) Ductile deformation of argillaceous sedimentary rock fragments (srf) reduces IGV to low levels. The SRFs contain significant microporosity. Sample 07JRM002-7.0A. (C) Fissile argillaceous sedimentary rock fragments (srf) deformed between two more rigid grains. Sample 07JRM002-7.0A. (D) Quartzose siltstone rock fragment is a relatively rigid grain compared to those with higher clay content. Sample 07JRM001-15.1A. (E) Fissile argillaceous sedimentary rock fragment (shale) containing minor quartz silt grains (arrows). Sample 07JRM001-15.1A. (F) Argillaceous chert grain with several quartz veins (arrows). These grains are highly resistant to ductile grain deformation. Sample 07JRM001-15.5A. 


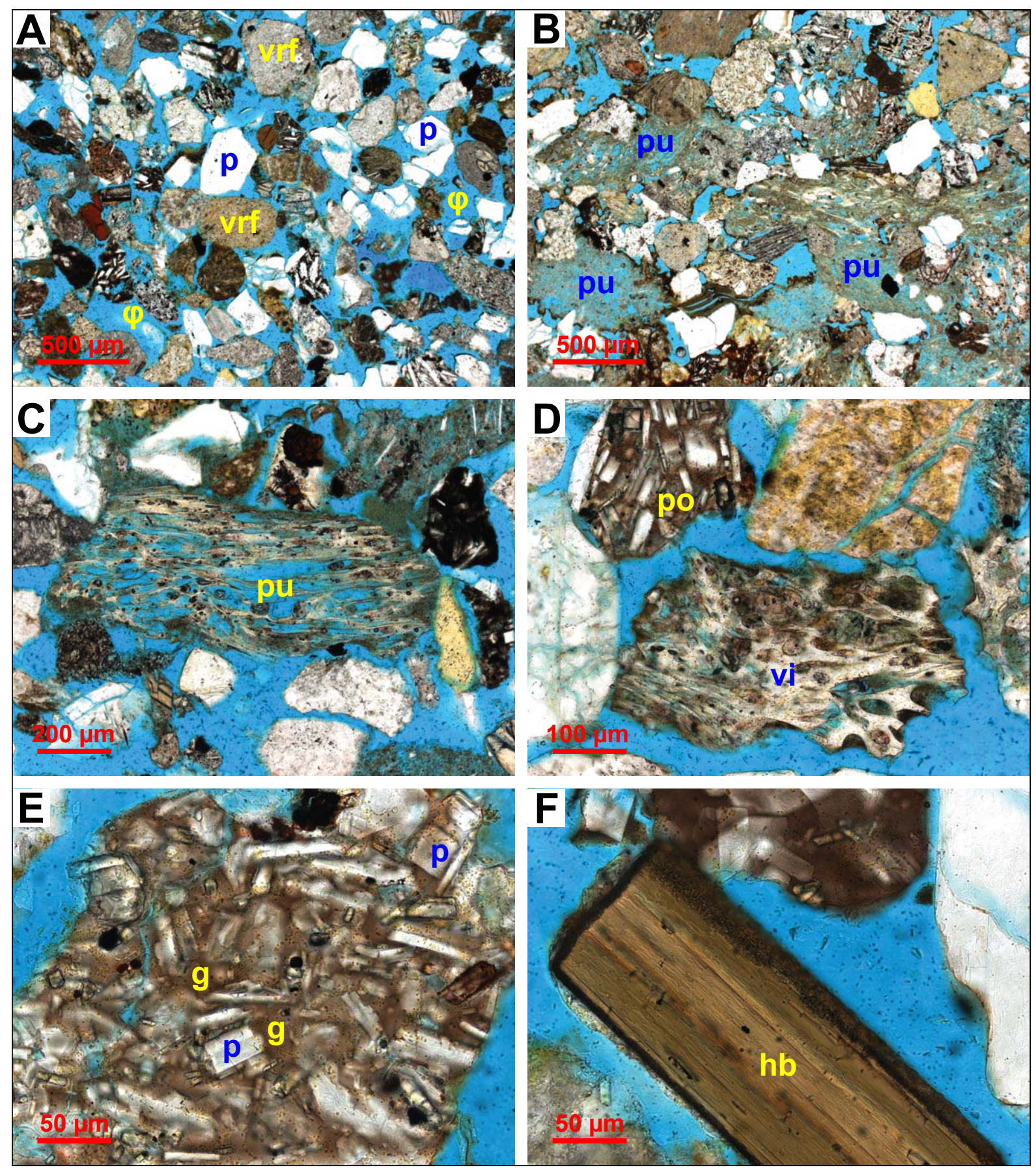

Figure 23. Photomicrographs of Sterling sandstones. (A) General view showing abundant volcanic rock fragments (vrf), plagioclase (p), and heavy minerals. Excellent reservoir quality results from extensive intergranular porosity ( $\varphi$ ). Sample 08DL006-0.4A. (B) Abundant pumice grains (pu) with significant microporosity due to vesicular texture. Sample 08DL007-0.8A. (C) Pumice fragment (pu) consisting largely of glass with vesicular texture. Sample 08DL006-10.8A. (D) Volcanic rock fragments with porphyritic (po) and vitrophyric (vi) textures are the dominant type of framework grain. Sample 08DL006-10.8A. (E) Porphyritic volcanic rock fragment with glassy groundmass (g) and plagioclase phenocrysts (p). Sample 08DL006-0.4A. (F) Pristine detrital hornblende grain (hb) suggests some volcanic detritus is syndepositional in origin. Sample 08DL006-0.4A. 
rock, indicating negligible porosity loss through cementation. As expected from its young age, relatively shallow burial, and lack of compaction or cementation, Sterling sandstones have very good to excellent reservoir quality with porosities in excess of 30 percent and permeabilities of several darcies (fig. 15), and comprise many of the shallow gas reservoirs in the inlet.

The volcanogenic composition and pristine appearance of most detrital grains suggest much of the sand was derived from an undissected magmatic arc. The detrital grains are interpreted to have been sourced from a mixture of older undissected segments of the Alaska-Aleutian Range volcanic arc and penecontemporaneous volcanic edifices ejecting pumiceous material, with possible additional contributions from the Alaska Range orogen and recycled strata from the collapsed Matanuska Valley segment of the forearc basin.

\section{WEST FORELAND-HEMLOCK PROVENANCE TRANSITION}

A poorly documented provenance transition may occur between the West Foreland and Hemlock Formations (fig. 12). Sandstones of the West Foreland Formation are distinctly volcaniclastic with a high $\mathrm{P} / \mathrm{F}$ ratio indicating detritus was largely sourced from an undissected volcanic arc complex (fig. 12). In stark contrast, sandstones of the Hemlock Formation are fairly quartzose with a low P/F ratio suggesting detritus is largely derived from the dissected arc and/or plutons in which granite, granodiorite, and tonalite were the dominant lithologies. One sandstone sample (09MAW335A) appears to be transitional between the compositional end-members. In the field it is interbedded with conglomerates consisting largely of volcanic clasts and was initially thought to belong to the West Foreland Formation. Detailed modal analysis shows it has a mixed mineralogy and plots between the West Foreland and Hemlock fields on ternary diagrams (fig. 12). Based on its transitional detrital composition, it is tempting to group it with the Hemlock sandstones.

This sample is likely from the upper portion of the West Foreland that contains both significant volcanic conglomerates and sandstones with a transitional (more quartzose) mineralogy. It is acknowledged this suggested transition, which is based on a single sample, is highly speculative and that additional fieldwork is needed to clarify the relationship.

\section{BELUGA-STERLING PROVENANCE TRANSITION}

The detailed modal analyses of the Sterling and Beluga sandstones in our data set (tables 2-4) suggest there is an evolution in provenance of the sandstones through time. There appears to be a transition from middle Beluga sandstones with a solely argillaceous composition, through upper Beluga and lower Sterling sandstones with a mixed mineralogy, to upper Sterling sandstones with a significant volcaniclastic component (fig. 13A). Sandstones from the middle portion of the Beluga Formation collected at Fritz Creek (reference numbers 28-57 in figs. 3 and 13B) consist almost exclusively of argillaceous sedimentary and metasedimentary rock fragments with only minor quartz and virtually no volcanic detritus (fig. 13A). They are believed to be representative of Beluga sandstones from the lower and middle portions of the formation. This detritus is interpreted to have been derived largely from the subduction complex and/or sources in the Alaska Range orogen represented by the Kahiltna assemblage north of Cook Inlet basin.

Sandstones from the upper Beluga Formation collected at Bidarka Creek (reference numbers 60-75 in figs. 3 and 13B) have a mixed mineralogy consisting of argillaceous SRFs/MRFs, VRFs, plagioclase, and amphiboles. Likewise, sandstones from the lower Sterling Formation collected at Falls Creek (reference numbers $1-5$ in figs. 3 and 13B) consist of a similar mixture of argillaceous SRFs/MRFs, VRFs, and plagioclase detritus. These sandstones are interpreted to have been derived from multiple sources including the subduction complex, Kahiltna assemblage, Alaska Range orogen, and recycled older Cenozoic formations in Matanuska Valley.

Sandstones from the upper portion of the Sterling Formation collected at Clam Gulch (reference numbers 6-23 in figs. 4 and 13B), are very volcanogenic (fig. 13A) with abundant VRFs, a very high P/F ratio, significant quantity of detrital amphiboles, and common pumice and unaltered glass fragments probably of pyroclastic origin. These sediments are interpreted to have been sourced from a mixture of older, undissected segments of the Alaska-Aleutian Range volcanic arc, penecontemporaneous volcanic edifices ejecting pumiceous material, and the Alaska Range orogen (tables 2-4, fig. 13).

In summary, during the middle Miocene when the lower Beluga Formation was deposited, detritus was derived almost exclusively from source terranes composed dominantly of shale and argillite. The Chugach accretionary complex on the east side of the basin is assumed to be the dominant source of the argillaceous material but the Kahiltna assemblage north of Cook Inlet is a possible secondary source. Starting around 8-10 Ma (middle-upper 
Miocene) an additional sediment source gradually became more prominent on the west side of the basin in the Alaska-Aleutian Range volcanic arc complex, yielding both epibasinal volcanic and coeval pyroclastic material. Through time an increasing proportion of sediment was derived from this western volcanic provenance. The transition culminated around $4 \mathrm{Ma}$ (middle Pliocene) when the eastern sediment source was shut off and detritus was solely derived from the Aleutian-Alaska Range volcanic arc and collisional sources to the north and west of the basin. This discussion assumes the argillaceous sedimentary and metasedimentary detritus was derived largely from the Chugach accretionary complex, with minor northerly input from the Kahiltna complex. While this is the simplest interpretation, additional work is needed to ascertain its validity.

\section{TECTONIC IMPLICATIONS OF SANDSTONE COMPOSITION}

The influence of plate tectonics on provenance, and hence sandstone composition, for modern sands and ancient sandstones was evaluated by Dickinson and Suczek (1979), Ingersoll and Suczek (1979), Dickinson (1982), Dickinson and others (1982, 1983), Suczek and Ingersoll (1985), and Dickinson (1985). This work shows that accurate determination of detrital sandstone modes, presented in a series of ternary diagrams, can facilitate the assessment of provenance for most sandstone suites and contribute to understanding the tectonic setting of depositional basins. The QtFL diagram (fig. 14A) displays total grain populations with all quartzose grains apportioned to the Q-pole, thereby emphasizing grain stability and hence weathering, relief, and transportation (Dickinson and Suczek, 1979). Fields delineating the mean detrital modes of the provenance types recognized by Dickinson (1985) are included for comparison.

The Tuxedni-Naknek-West Foreland-Sterling suites largely plot within the field of magmatic arc provenance. Tuxedni, West Foreland, and Sterling sandstones consist dominantly of aphanitic VRFs and are inferred to have a provenance in an undissected segment of the Aleutian-Alaska Range arc. Sterling sandstones possibly have a secondary northern source in the Matanuska Valley and central Alaska Range (Finzel, 2010). Naknek sandstones, which consist largely of plagioclase, hornblende, opaque minerals, and minor quartz, have a provenance in deeply dissected arc segments.

Tyonek and Hemlock sandstones plot largely within the field of recycled orogen provenance. The Upper Jurassic to Upper Cretaceous Kahiltna assemblage in the Talkeetna Mountains and southern flank of the central Alaska Range is part of a Mesozoic collisional orogen, which probably shed quartzose sediment southward into Cook Inlet (Finzel and others, 2011; Kalbas and others, 2007; Trop and Ridgway, 2007; Trop and others, 2003; Eastham and Ridgway, 2000). By early Miocene time, the western and eastern segments of the Alaska Range were being exhumed (Benowitz and others, 2011; Haeussler and others, 2008), thus it is conceivable that deeply dissected parts of the Alaska Range also contributed quartz and K-feldspar to Hemlock and Tyonek sandstones. Tertiary closure of the Matanuska segment of the forearc basin may have shed quartzose sediment southward into the Upper Cook Inlet segment of the basin as well.

Beluga sandstones, which plot close to the L-pole due to the preponderance of argillaceous sedimentary and metasedimentary lithic grains (such as mudstone, siltstone, argillite, phyllite), do not plot in any of the recognized provenance fields. The argillaceous grains are most likely derived from a portion of the subduction complex deficient in sandstones and may represent fine-grained, deep-sea sediments rafted into the trench. The Kahiltna assemblage to the north probably also supplied argillaceous detritus. Assuming most of the Beluga detritus was derived from the Chugach accretionary complex, this suggests the recycled orogen provenance field of Dickinson (1985), which includes the subduction complex provenance, may actually extend further down the QL-join towards the L-pole than previously reported.

The QpLvmLsm diagram (fig. 14B) displays only partial grain populations, but discloses the nature of the polycrystalline components of the sandstone framework. Fields delineating the mean detrital modes of the provenance types recognized by Dickinson (1985) are included for comparison. As expected, the Tuxedni-West Foreland suites, which are sourced mainly in undissected arc segments, plot largely in the magmatic arc provenance field. Naknek sandstones are excluded from the diagram because they typically contain less than 10 percent aphanitic lithic fragments and, after normalization, the QpLvmLsm ratios are skewed. Hemlock and Tyonek sandstones, which are partially sourced from a collisional orogen north and west of the forearc basin, largely overlap the recycled orogen provenance field. Beluga sandstones plot in portions of both the recycled orogen and magmatic arc provenances. Lower to middle Beluga sandstones are enriched in argillaceous framework grains and plot largely

in the recycled orogen provenance field. Upper Beluga sandstones are transitional, containing both argillaceous $\mathrm{SRF} / \mathrm{MRF}$ s and VRFs and, as a result, plot midway between the recycled orogen and magmatic arc provenance 
fields, reflecting the gradational change in composition from Beluga to Sterling sandstones. The overlying Sterling sandstones, which are highly volcanogenic, plot largely in the magmatic arc provenance field.

\section{SUMMARY OF RESERVOIR QUALITY}

The reservoir quality of Cook Inlet sandstones varies widely depending on their mineralogy, geologic age, burial depth, and depositional environment. Porosities less than 5 percent and permeabilities less than 1 millidarcy are characteristic of the poorer reservoirs, while porosities greater than 35 percent and permeabilities in excess of several darcies are common in the better ones. The poorer reservoirs are geologically older, more deeply buried, and have a labile mineralogy consisting largely of volcanic rock fragments and plagioclase. Regionally they comprise the "zone of diagenetic control" in which reservoir quality is largely a function of the compaction and cementation history of the rocks. The better reservoirs are generally characterized by relatively young geologic age, shallow burial depths, and stable framework mineralogy. In a regional sense, these sandstones comprise the "zone of depositional control", where reservoir quality is largely controlled by textural parameters related to depositional environment, and only minimally degraded by diagenetic processes, and hence have high potential as conventional hydrocarbon reservoirs.

Tuxedni and Naknek sandstones have poor reservoir quality and are likely to be of equally poor quality down dip. They are affected by the triple threat of deep burial, old age, and labile mineralogy. Primary porosity has been reduced to residual values by the combination of mechanical compaction and cementation. Tuxedni sandstones have extensive authigenic pore-filling clay derived from the alteration of VRFs, while Naknek sandstones are characterized by extensive zeolite cementation resulting from the aleration of abundant detrital calcic plagioclase. Despite this, both have potential to comprise unconventional reservoirs, particularly tight gas sands and fractured reservoirs. As mentioned above, the potential may exist to find Naknek sandstones with a much lower P/F ratio along the west side of the basin. That could increase the reservoir potential of those sandstones; however, more fieldwork is needed to evaluate this hypothesis.

The "Saddle Mountain" sandstones (only two samples examined) have mixed reservoir quality. Based on their quartzose-feldspathic composition with low $\mathrm{P} / \mathrm{F}$ ratio, they have potential to comprise good reservoirs in the basin. Good reservoir quality was encountered in correlative rocks in the ARCO Raven \#1 well located east of Saddle Mountain in Federal OCS waters of lower Cook Inlet (LePain and others, 2012). The extent of clay and carbonate cementation is difficult to quantify based on the limited sample set and should be addressed in future fieldwork.

West Foreland sandstones examined have poor reservoir quality and are negatively influenced by their immature volcanic mineralogy. More deeply buried West Foreland sandstones in the center of the basin are expected to have equally poor reservoir quality, if not worse. The labile nature of VRFs and plagioclase are sure to result in extensive clay and zeolite cementation. Due to the ductile nature of most VRFs, they are also prone to extensive ductile grain deformation.

The Hemlock and Tyonek sandstones have good to excellent reservoir quality, largely resulting from their quartzose-feldspathic mineralogy that is physically and chemically stable and burial depths generally less than $3,000 \mathrm{~m}$. These sandstones are characterized by a well-developed intergranular pore system that is modified by compaction and authigenic clay cementation. Within these reservoirs, depositional environment also affects reservoir quality. The coarser-grained sandstones and conglomerates typical of channel facies form the better reservoirs while siltstones and mudstones of the overbank and other fine-grained facies are generally of much poorer quality. Of all the sandstones examined, they have the most potential to retain their reservoir quality at significant burial depths in the center of the basin. It is no surprise they comprise some of the best reservoirs yet discovered in the basin.

The Beluga and Sterling sandstones are among those with the best reservoir quality of all the outcrop samples examined (fig. 15). This results from their young age and shallow burial, despite having compositions susceptible to extensive diagenetic modifications. Similar sandstones located at depth in the central portion of the basin probably have lower reservoir quality. At significant burial depths Beluga sandstones would be subjected to extensive ductile grain deformation while Sterling sandstones would be susceptible to extensive cementation by authigenic clays and zeolites. Having said that, both the Beluga and Sterling sandstones are productive reservoirs in the center of the basin at North Cook Inlet field, so the increased burial likely had a minimal effect on reservoir quality.

It should be emphasized that our observations are based on a limited number of outcrop samples collected from widely dispersed localities. As such, we have only "scratched the surface" in addressing the reservoir quality and reservoir potential of Tertiary and Mesozoic sandstones of the Cook Inlet basin. Additional insights into these issues will be made available as warranted by new data. 


\section{ACKNOWLEDGMENTS}

The samples analyzed in this report were collected over four field seasons by many geologists from several agencies, often working in remote settings. Their assistance is gratefully acknowledged. They include Rick Stanley (U.S. Geological Survey); Marwan Wartes, Bob Gillis, Trystan Herriott, Dave Mauel (Alaska Division of Geological \& Geophysical Surveys); Paul Decker, Laura Gregersen, Diane Shellenbaum, Meg Kremer (Alaska Division of Oil and Gas); Paul McCarthy, Jake Mongrain, Keane Richards (University of Alaska Fairbanks). We thank William R. Dickinson for discussions on interpreting tectonic settings from sandstone detrital modes. The manuscript benefited greatly from the review of Bob Gillis, although the authors take sole responsibility for its content. Special thanks go to Merlin "Spanky" Handley of Pathfinder Aviation for his professionalism, affable demeanor, and skill in shepherding us in the field.

\section{REFERENCES CITED}

Benowitz, J.A., Layer, P.W., Armstrong, P., Perry, S.E., Haeussler, P.J., Fitzgerald, P.G., and Van Laningham, S., 2011, Spatial variations in focused exhumation along a continental-scale strike-slip fault-The Denali fault of the eastern Alaska Range: Geosphere, v. 7, p. 455-467.

Boles, J.R., 1982, Active albitization of plagioclase, Gulf Coast Tertiary: American Journal of Science, v. 282, p. $165-180$.

Boles, J.R., and Coombs, D.S., 1977, Zeolite facies alteration of sandstones in the Southland syncline, New Zealand: American Journal of Science, v. 277, p. 982-1,012.

Coombs, D.S., 1954, The nature and alteration of some Triassic sediments from Southland, New Zealand: Royal Society of New Zealand Transactions, v. 82, p. 65-109.

Curry, R.P., Simpson, H.M., Doherty, D.J., McGowen, J.H., Gresko, M.J., and Bergman, S.C., 1990, Tertiary stratigraphic framework, Cook Inlet-Matanuska Valley, Alaska, in Curry, R.P., technical coordinator, Nonmarine basins project-Tertiary upper Cook Inlet forearc basin, ARCO Exploration Research Report RR90-0002, p. 79-92.

Decker, J.E., 1985, Sandstones modal analysis procedure: Alaska Division of Geological \& Geophysical Surveys Public Data File 85-3, 38 p.

Decker, J.E. and Helmold, K.P., 1985, The effect of grain size on detrital modes: A test of the Gazzi-Dickinson point-counting method-Discussion: Journal of Sedimentary Petrology, v. 55, p. 618-620.

Detterman, R.L., and Hartsock, J.K., 1966, Geology of the Iniskin-Tuxedni Peninsula region, Alaska: U.S. Geological Survey Professional Paper 512, 78 p., 7 plates.

Dickinson, W.R., 1970, Interpreting detrital modes of graywacke and arkose: Journal of Sedimentary Petrology, v. 40 , p. $695-707$.

1982, Compositions of sandstones in Circum-Pacific subduction complexes and fore-arc basins: American Association of Petroleum Geologists Bulletin, v. 66, p. 121-137.

1985, Interpreting provenance relations from detrital modes of sandstones, in Zuffa, G.G., ed., Provenance of Arenites: NATO Advanced Science Institutes Series C-Mathematical and Physical Sciences, D. Reidel Publishing Co., v. 148, p. 333-361.

Dickinson, W.R., Ingersoll, R.V., Cowan, D.S., Helmold, K.P., and Suczek, C.A., 1982, Provenance of Franciscan graywackes in coastal California: Geological Society of America Bulletin, v. 93, p. 95-107.

Dickinson, W.R., Beard, L.S., Brakenridge, G.R., Erjavec, J.L., Ferguson, R.C., Inman, K.F., Knepp, R.A., Lindberg, F.A., and Ryberg, P.T., 1983, Provenance of North American Phanerozoic sandstones in relation to tectonic setting: Geological Society of America Bulletin, v. 94, p. 222-235.

Dickinson, W.R., and Suczek, C.A., 1979, Plate tectonics and sandstone compositions: American Association of Petroleum Geologists Bulletin, v. 63, p. 2,164-2,182.

Eastham, K.R., and Ridgeway, K.D., 2000, Stratigraphic and provenance data from the Upper Jurassic to Upper Cretaceous Kahiltna assemblage of south-central Alaska: U.S. Geological Survey Professional Paper 1662, p. 45-53.

Egbert, R.M., 1982, Sedimentology and petrography of Middle and Upper Jurassic rocks in Tuxedni Bay area, Cook Inlet, Alaska: San Jose State University, unpublished M.S. thesis, 128 p.

1986, Petrography, provenance, and tectonic significance of Middle and Upper Jurassic sandstones from Tuxedni Bay, in Magoon, L.B., ed., Geologic Studies of the Lower Cook Inlet COST No. 1 Well, Alaska Outer Continental Shelf, U.S. Geological Survey Bulletin 1596, p. 61-63. 
Finzel, E.S., 2010, Geodynamics of flat-slab subduction, sedimentary basin development, and hydrocarbon systems along the southern Alaska convergent plate margin: West Lafayette, Indiana, Purdue University, unpublished Ph.D. dissertation, $396 \mathrm{p}$.

Finzel, E.S., Trop, J.M., Ridgway, K.D., and Enkelmann, E., 2011, Upper-plate proxies for flat-slab subduction in southern Alaska: Earth and Planetary Science Letters, v. 303, p. 348-360.

Folk, R.L., 1974, Petrology of sedimentary rocks: Hemphill Publishing Co., Austin, TX, 182 p.

Franks, S.G., and Hite, D.M., 1980, Controls of zeolite cementation on Upper Jurassic sandstones, lower Cook Inlet, Alaska [abs.]: American Association of Petroleum Geologists Bulletin, v. 64, p. 708-709.

Gazzi, P., 1966, Le arenarie del flysch sopracretaceo dell'Appennino modernese: Correlazioni con il flysch di Monghidoro: Mineralogica e Petrografica Acta, v. 12, p. 69-97.

Graham, S.A., Ingersoll, R.V., and Dickinson, W.R., 1976, Common provenance for lithic grains in Carboniferous sandstones from Ouachita Mountains and Black Warrior Basin: Journal of Sedimentary Petrology, v. 46, p. 620-632.

Haeussler, P.J., O’Sullivan, Paul, Berger, A.L., and Spotila, J.A., 2008, Neogene exhumation of the Tordrillo Mountains, Alaska, and correlations with Denali (Mount McKinley), in Freymueller, J.T., Haeussler, P.J., Wesson, R.L., and Ekstrom, G., eds., Active Tectonics and Seismic Potential of Alaska: American Geophysical Union Geophysical Monograph 179, p. 269-285.

Hampton, B.A., Ridgway, K.D., O’Neill, M.J., Gehrels, G.E., Schmidt, J., and Blodgett, R.B., 2007, Pre-, syn-, and post-collisional stratigraphic framework and provenance of Upper Triassic-Upper Cretaceous strata in the northwestern Talkeetna Mountains, Alaska: Geological Society of America Special Paper 431, p. 401-438.

Hastings, D.S., Robinson, A.G., and Robinson, N.M., Jr., 1983, Stratigraphy, depositional history, and reservoir potential of Cretaceous and early Tertiary rocks of lower Cook Inlet, Alaska [abs.]: American Association of Petroleum Geologists Bulletin, v. 67, no. 3, p. 480.

Helmold, K.P., 2013, Reservoir quality of sandstones in the Naknek and Kaguyak Formations_-Field observations, in Gillis, R.J., ed., Overview of 2012 field studies-Upper Alaska Peninsula and west side of lower Cook Inlet, Alaska: Alaska Division of Geological \& Geophysical Surveys Preliminary Interpretive Report 2013-1, p. 11-12.

Helmold, K.P., and van de Kamp, P.C., 1984, Diagenetic mineralogy and controls on albitization and laumontite formation in Paleogene arkoses, Santa Ynez Mountains, California, in McDonald, D.A., and Surdam, R.C., eds., Clastic diagenesis: American Association Petroleum Geologists Memoir, v. 37, p. 239-276.

Helmold, K.P., LePain, D.L., Wartes, M.A., Stanley, R.G., Gillis, R.J., Peterson, C.S., and Herriott, T.M., 2011, Reservoir potential of Tertiary and Mesozoic sandstones, Cook Inlet, Alaska: American Association of Petroleum Geologists, Pacific Section Annual Meeting, p. 61.

Herriott, T.M., Wartes, M.A., Stanley, R.G., Lillis, P.G., Helmold, K.P., Decker, P.L. and Gillis, R.J., 2013, Oilstained sandstones of the Upper Jurassic Naknek Formation and Upper Cretaceous Kaguyak Formation, Kamishak area, lower Cook Inlet, Alaska [abs.]: American Association of Petroleum Geologists, Pacific Section Annual Meeting.

Iijima, Azuma and Utada, Minoru, 1971, Present-day zeolite diagenesis of the Neogene geosynclinal deposits in the Niigata Oil Filed, Japan: Advances in Chemistry Series 101, American Chemical Society, p. $342-349$.

Ingersoll, R.V., and Suczek, C.A., 1979, Petrology and provenance of Neogene sand from Nicobar and Bengal fans, DSDP sites 211 and 218: Journal of Sedimentary Petrology, v. 49, p. 1,217-1,228.

Ingersoll, R.V., Bullard, T.F., Ford, R.L., Grimm, J.P., Pickle, J.D., and Sares, S.W., 1984, The effect of grain size on detrital modes-A test of the Gazzi-Dickinson point-counting method: Journal of Sedimentary Petrology, v. 54, p. 103-116.

Kalbas, J.L., Ridgway, K.D., and Gehrels, G.E., 2007, Stratigraphy, depositional systems, and provenance of the Lower Cretaceous Kahiltna assemblage, western Alaska Range_-Basin development in response to oblique collision: Geological Society of America Special Paper 431, p. 307-343.

Langford, S.M., and Magoon, L.B., 1978, Petrography of the Upper Jurassic through Oligocene sandstones in the Cape Douglas-Kamishak Hills area, lower Cook Inlet: U.S. Geological Survey Circular 772-B, p. 60-62.

LePain, D.L., Lillis, P.G., Helmold, K.P., and Stanley, R.G., 2012, Migrated hydrocarbons in exposure of Maastrichtian nonmarine strata near Saddle Mountain, lower Cook Inlet, Alaska: Alaska Division of Geological \& Geophysical Surveys Report of Investigation 2012-1, 19 p.

Little, T.A., and Naeser, C.W., 1989, Tertiary tectonics of the Border Ranges fault system, Chugach Mountains, Alaska-Deformation and uplift in a forearc setting: Journal of Geophysical Research, v. 94, p. 4,333-4,359. 
Magoon, L.B., Griesbach, F.B., and Egbert, R.M., 1980, Nonmarine Upper Cretaceous rocks, Cook Inlet, Alaska: American Association of Petroleum Geologists Bulletin, v. 64, p. 1,259-1,266.

McCulloch, T.H., 1981, Mid-Tertiary laumontite isograd offset $37 \mathrm{~km}$ by left-lateral strike-slip on Santa Ynez Fault, California: American Association of Petroleum Geologists Bulletin, v. 65, p. 956.

McLean, H., 1979, Sandstone petrology-Upper Jurassic Naknek Formation of the Alaska Peninsula and coeval rocks on the Bering Shelf: Journal of Sedimentary Petrology, v. 49, p. 1,263-1,268.

1986, Sandstone petrography, in Magoon, L.B., ed., Geologic Studies of the Lower Cook Inlet COST No. 1 Well, Alaska Outer Continental Shelf: U.S. Geological Survey Bulletin 1596, p. 47-49.

Merino, E., 1975, Diagenesis in Tertiary sandstones from Kettleman North Dome, California, Part I, Diagenetic mineralogy; Journal of Sedimentary Petrology, v. 45, p. 320-336.

Nokleberg, W.J., Plafker, George, and Wilson, F.H., 1994, Geology of south-central Alaska, in Plafker, George, and Berg, H.C., eds., The Geology of Alaska: Geological Society of America, The Geology of North America, v. G-1, p. 311-366.

Plafker, George, Nokleberg, W.J., and Lull, J.S., 1989, Bedrock geology and tectonic evolution of the Wrangellia, Peninsular, and Chugach terranes along the Trans-Alaska Crustal Transect in the Chugach Mountains and southern Copper River basin, Alaska: Journal of Geophysical Research, v. 94, p. 4,255-4,295.

Suczek, C.A., and Ingersoll, R.V., 1985, Petrology and provenance of Cenozoic sand from the Indus cone and the Arabian Basin, DSDP sites 221, 222, and 224: Journal of Sedimentary Petrology, v. 55, p. 340-346.

Swenson, R.F., 2003, Introduction to Tertiary tectonics and sedimentation in the Cook Inlet basin, in Dallegge, T.A., compiler, 2001 Guide to the petroleum geology and shallow gas potential of the Kenai Peninsula, Alaska: Alaska Division of Geological \& Geophysical Surveys Miscellaneous Publication 128, p. 10-19.

Trop, J.M., and Ridgway, K.D., 2007, Mesozoic and Cenozoic tectonic growth of southern Alaska-A sedimentary basin perspective: Geological Society of America Special Paper 431, p. 55-94.

Trop, J.M., Ridgway, K.D., and Spell, T.L., 2003, Sedimentary record of transpressional tectonics and ridge subduction in the Tertiary Matanuska Valley_Talkeetna Mountains forearc basin, southern Alaska: Geological Society of America Special Paper 371, p. 89-118.

Wilson, M.D., 2002, Petrographic provenance analysis of Kiowa Core sandstone samples, Denver Basin, Colorado: Rocky Mountain Geology, v. 37, p. 173-187. 